\title{
The effects of ownership structure, sub-optimal cash holdings and investment inefficiency on dividend policy: evidence from Indonesia
}

\author{
Abdul Moin ${ }^{1} \cdot$ Yilmaz Guney $^{2} \cdot$ Izidin El Kalak ${ }^{3}$ D
}

(C) The Author(s) 2019

\begin{abstract}
We investigate how a firm's decision to hold excessive cash or to overinvest could influence its dividend payout policy in Indonesia. Additionally, we examine the association between corporate ownership structure and cash dividends. Using a data set of Indonesian listed firms for the period from 1995 to 2014, we find that excessive cash holding (overinvestment) positively (negatively) affects a firm's likelihood of paying dividends. Also, we find that family, foreign, state and institutional ownership have significantly negative links with dividends, which suggests the signals of expropriation of firms' wealth by major shareholders. These findings strongly support the expropriation hypothesis that commonly applies to firms with higher level of concentration or to firms in a weak legal environment by which the rights of minority interests are put at risk by large shareholders.
\end{abstract}

Keywords Dividend policy · Overcash · Overinvestment · Corporate governance · Ownership structure $\cdot$ Indonesia

JEL Classification G32 · G34 · G35

\section{Izidin El Kalak}

elkalaki@cardiff.ac.uk

Abdul Moin

abdul.moin@uii.ac.id

Yilmaz Guney

y.guney@hull.ac.uk

1 Accounting and Finance Department, Faculty of Economics, Islamic University of Indonesia, Yogyakarta, Indonesia

2 Accounting and Finance Department, Business School, University of Hull, Hull, UK

3 Accounting and Finance Department, Business School, Cardiff University, Aberconway Building, Column Drive, Cardiff, UK 


\section{Introduction}

Agency theory indicates that there are some potential problems when firms hold overcash (i.e., excessive cash holding) which can be related to managerial overcompensation and overinvestment (Jensen 1986; Fairchild 2010). Overcompensation and overinvestment can be intertwined as corporate managers could use cash flows to be invested in negative net present value (NPV) projects, which leads to managerial private benefits and to enhance managerial overcompensation due to the increasing scale of duty, firm size, and responsibility (Jensen and Meckling 1979). On the other hand, such actions could be harmful to shareholders since some cash should be returned to them. Fuller and Blau (2010) name this situation as the "free cash flow problem" and to reduce this problem firms should pay dividends to their shareholders.

In this study, we sought to address the following two questions: Is there any link between the decision to hold overcash and to overinvest and a firm's dividend policy? Is there any association between a firm's corporate governance, represented by ownership structure and types, and its dividend policy?

Therefore, our analysis focuses on two closely related issues. First, we examine the relation between a firm's decision to hold overcash and to overinvest and dividend payout policy. The deviation from a firm's optimal financial decisions, such as optimal cash holdings and optimal investment is a well-investigated area of research (e.g., Jiang and Lie 2016; Lin and Chiu 2017). Prior literature proposes several explanations as to why firms deviate from their optimal cash holding levels or optimal investments. One explanation is that managers are risk averse and therefore holding overcash is intended to avoid the firm's default and avoid market discipline (Opler et al. 1999); another explanation is that overcash gives managers greater flexibility to pursue their own objectives (Pinkowitz et al. 2006). These reasons are consistent with the free cash flow hypothesis (Easterbrook 1984) arguing that managers endowed with overcash could invest in projects having negative NPV rather than making payouts to shareholders (Lang et al. 1995). Further, Opler et al. (1999) also explain that overcash benefits the management to fund, whenever it wants to, investment projects, which outside creditors or investors are not interested in financing. Both overcash and overinvestment are conditions where a firm is unbalanced as a result of the managerial decisions, which are not convergent with shareholders' interest. Richardson (2006) argues that overcash and overinvestment have impacts on managers' behavior that lead to substantial agency costs borne by shareholders.

Holding specific cash balances and making investments are managers' strategic decisions, which have effects on many other decisions, such as dividend payments, while the intensity of cash dividend payment is determined by the availability of cash held by the firm. A considerable number of researchers investigate the association between overcash and performance (Mikkelson and Partch 2003; Dittmar and Mahrt-Smith 2007), overinvestment and firm performance (Fu 2010), overinvestment and free cash flow (Richardson 2006), overinvestment and dividend initiation announcement returns (Officer 2011). However, to our best knowledge, there is no study yet that addresses the effect of a firm's decision to hold overcash and to overinvest on their dividend payout policy.

We next examine whether corporate ownership structure could alter a firm's dividend payout policy. According to the agency theory, dividend policy as a product of a firm's decision can be vulnerable to the abuses by powerful controlling shareholders to take private benefits. La Porta et al. (2000b) show that, on the country level, minority shareholders in countries with weak investor protection receive lower dividends than those in countries 
with strong legal protection of minority shareholders. Furthermore, La Porta et al. (2000a) contend that minority shareholders are well protected when their voting rights are properly enforced. Therefore, a country's institutional characteristics have to be considered when studying payout policy to help explaining the changes in the propensity to pay dividends (Baker et al. 2012). Empirical evidence shows that the majority shareholders use their firms' cash flows for their own benefits, which would be detrimental to minority shareholders (Faccio et al. 2001).

We find that overcash and overinvestment variables affect significantly the propensity of firms to pay cash dividends. Therefore, firms that hold cash over their optimal target level tend to be more likely to pay dividends, whereas for firms that overinvest this tendency reduces. When testing the association between corporate ownership and dividend policy, we find that the percentage of family ownership negatively affects the likelihood of firms to pay dividends. This finding suggests that family firms persistently retain profit to be invested within the firm to pursue the firm's growth. It also suggests that managers of family firms are under strict control by family-related shareholders and they have made dividend decisions to the detriment of the minority shareholders. The findings thus tend to support the expropriation hypothesis, by which the rights of minority interests are put at risk by family stock owners. On the other hand, foreign investors and managerial ownership tend to have positive impacts on the propensity to pay dividends. These findings strongly support the hypothesis which commonly applies to firms with higher level of concentration or to firms in a weak legal environment by which firms use cash to be shifted to other businesses among their groups.

Our study provides three-folded contributions by further adding to the existing literature on dividend policy: Our first contribution is to investigate the effects of holding overcash and the decision to overinvest on a firm's dividend policy. By doing so, we extend the previous studies that investigate the determinants of payout policy (e.g., Fuller and Blau 2010; Twu 2012; Jacob and Michaely 2017). In addition, we distinguish our work from the extant literature in terms of the measurements used for overcash and overinvestment and explicitly test their effects on dividends payout policy. For example, Officer (2011) examines the market reaction to dividend initiations while controlling for cash holding defined as overcash relative to industry peers and overinvestment using Tobin's Q measure. For our analysis, we use overinvestment based on Richardson's (2006) model which appears to be a robust measure of overinvestment. ${ }^{1}$ Similarly, Holder et al. (1998), Mikkelson and Partch (2003), and Dittmar and Mahrt-Smith (2007) use overcash to measure cash holdings, while we relied on the residuals from the excess cash regression produced by fitting Opler et al.'s (1999) model, where we report different results from that of Mikkelson and Partch (2003) who find that high cash firms do not pay high dividends.

Secondly, we further contribute to previous studies that have tested the effect of corporate governance on dividend policy (e.g., Baker et al. 2012; Ben-Nasr 2015). We differentiate our study from previous studies by investigating the effect of various ownership types (i.e., family, foreign, state, managerial, and institutional) and ownership concentration on dividend policy in the context of principal-principal conflict of interest that generally occurs in a concentrated ownership structure while taking into account sub-optimal cash holding and investment inefficiencies.

\footnotetext{
${ }^{1}$ Richardson's construct is used by previous studies such as Chen et al. (2016).
} 
Finally, we examine the practices of dividend policy in Indonesia where a strong domination and control of a few shareholders exist. In the Indonesian market, a typical emerging market, large blockholders play a significant role in controlling firms' decisions. Additionally, in a large and growing body of literature in the last few decades, dividend policy has been highlighted from the perspective of another form of agency theory: a conflict of interest between controlling shareholders and minority shareholders.

There are several reasons why we use Indonesian data. Firstly, it has unique organizational forms, business practices, social structure, and political ties which could be inconsistent with value-creating business strategies (Ang et al. 1997; Leuz and Oberholzer-Gee 2006). In addition, the unique social, political and business environment combined with the substantial growth of Indonesia capital markets, this study could broaden the financial literature which are dominated by studies focusing on developed markets. Secondly, the agency conflict between managers' use of overcash and overinvestment on dividends could be more significant in Indonesian firms than firms in other countries, especially those in developed economies. The dividend policy in developed countries, such as in the US, is known to be sticky and stable over a period of time, with investors having better exante expectations for dividend policy (Jiang et al. 2017). These developed countries enjoy more established regulations and rule of law, which makes it more reasonable for firms to pay dividends and harder to change the payout policy. On the contrary, the weak corporate governance framework in the Indonesian market coupled with weak regulations (e.g., Leuz and Wysocki 2016) make it easier for firms to change their dividend policy according to insiders' will; hence, using an Indonesian data set provides an important motivation to check the validity of the hypotheses about agency conflicts. Thirdly, different from the typical Anglo-American countries with widely dispersed ownership, Indonesian firms have strong domination and control in the hands of controlling shareholders. In addition, examining Indonesian listed firms characterised by their opaque information due to the underdeveloped accounting standards and weak regulation provides another good motivation to study this country which is different from the countries studied by La Porta et al. (1997) that include samples of more developed countries. Finally, the number of studies focusing on the firms' dividends policy in the Indonesian market is limited (e.g., Duygun et al. 2018); hence, given all the above reasons, it is important to shed some light on the Indonesian firms' behaviour with respect to their dividend payout policies.

The remainder of the paper is organized as follows. Section 2 discusses theoretical arguments for the determinants of cash dividends and formulates hypotheses to test. Section 3 contains data and empirical models. Section 4 presents empirical analyses and findings. Finally, Sect. 5 concludes.

\section{Literature review and hypotheses development}

\subsection{Overcash and dividend policy}

Opler et al. (1999) find that firms with higher growth opportunities and riskier cash flows hold high ratios of cash to total non-cash assets. Dividends paid by a firm depend on the firm's available free cash flow and its growth opportunities (Che et al. 2018). As proposed 
by the life-cycle theory, ${ }^{2}$ mature firms with abundant free cash flow tend to pay higher dividends than young and growing firms. Young firms still struggle to pursue investment opportunities by investing their free cash flow. Consequently, such firms pay lower dividends. Mature firms with a history of profitability should have larger free cash flows and accumulation of retained earnings as a source of financing. Firms with larger internal sources of funds can reduce the dependence of firms on external sources. On the other hand, higher cash flows lead to the escalation of agency conflict between shareholders and managers (Jensen 1986). To reduce such conflicts, dividends should be used as a device to monitor managers, to minimize the probability of using free cash flow for their own interest. Holder et al. (1998) and Guo (2016) find that there is a positive relation between cash flows and dividends, indicating that dividends are used as a tool to minimize agency conflict, as proposed by the agency theory. Regarding the measurement of free cash flow, Jensen (1986) uses overcash of the firm, while Denis and Osobov (2008) use the ratio of retained earnings to book equity, and Fama and French (2001) use the ratio of retained earnings to total assets.

The firm's ability to pay dividends, as one form of the use of funds, is determined by the firm's financial resources, such as retained earnings. According to the residual theory of dividend (Miller and Modigliani 1961), firms will only pay dividends as long as there is no investment giving positive net present value. This means that corporate profits should be retained to finance investment projects which support the firm's future revenues. Agency theory explains that dividends can be a tool to mitigate agency conflict between shareholders and managers (Jensen 1986). Jensen (1986) proposes the free cash flow theory, asserting that when a firm has free cash flow while there is no profitable investment, the firm should pay its cash to shareholders. This is to avoid the use of the firm's cash by managers to fulfill their own interests. The theory indicates that managers could use the firm's cash for their private benefits or for investing in unprofitable projects. To minimize the occurrence of these possibilities, shareholders could require a higher dividend as a tool to reduce agency costs (Borokhovich et al. 2005). In this type of control structure, minority shareholders are vulnerable to being expropriated by controlling shareholders (Gugler 2003). Agency theory predicts that shareholders prefer to receive dividends rather than let the extra cash flow be retained by the firm. Ceteris paribus, firms with larger cash flows pay more dividends when agency conflicts do not exist. We therefore propose the first set of hypotheses as follows:

H1a: The probability of firms paying dividends increases if the firms are holding overcash.

H1b: Firms with overcash pay larger dividends.

\subsection{Overinvestment and dividend policy}

Corporate managers make decisions whether the firm's cash flows will be retained as internally-generated capital or will be returned to the shareholders as dividends. The choice could depend on the availability of profitable projects. The theory of residual dividend

\footnotetext{
${ }^{2}$ Yu et al. (2015) provide supporting evidence in line with the life-cycle theory. They report significant differences in the drivers of cash holdings for firms which are more than 5 years old relative to firms which are less than 5 years old.
} 
argues that the cash flow should be prioritized to finance profitable investments which contribute to shareholder wealth maximization, whilst dividends are paid as residual, which occurs in the ideal world (Miller and Modigliani 1961). The consequence is that firms could pay less dividends although the firm obtains abundant cash flow. Consistent with pecking order theory (Myers and Majluf 1984), internally-generated capital will be the first choice of source of project funding since it is less costly than other external funds, such as debt or issuing stock. However, the question is whether the investments made by the firms are truly value-enhancing projects for the benefits of shareholders, or are sub-optimal projects, at the expense of shareholders, for the sake of managers' empire buildings (Fairchild 2010), non-productive acquisition (Harford 1999), and to obtain higher compensation (Jensen 1986). Further, Kuo (2013) finds a positive relation between cash dividends and the firm's future earnings response when the firm is in severe free cash flow problem. This indicates that higher cash payout reduces managerial over-investment. Overinvestment occurs when a firm spends more on investment projects than the average for firms in the same industry. This decision is a product of managers' over optimism regarding future returns of their projects (Ahmed and Duellman 2013). Easterbrook (1984) highlights an assumption that managers are not perfect agents of shareholders and managers try to pursue their benefits, causing a divergence of interest between managers and shareholders. Richardson (2006) provides a theoretical foundation for overinvestment theory, suggesting that managers could overinvest when the firm has more cash flow. Firms with overinvestment tend to spend more cash that, in turn, will affect firm's ability to pay dividends. Ceteris paribus, over investing firms will pay low dividends. Thus, we posit that:

H2a: The probability of paying dividends decreases if a firm is overinvesting.

H2b: Firms with overinvestment inefficiencies pay less dividends.

\subsection{Corporate governance and dividend policy}

Shleifer and Vishny (1997) argue that large shareholders tend to accumulate more cash and pay lower dividends. In addition, they point out that large shareholders can take a number of measures to expropriate firm assets through intra group sales and service and transfer pricing, whereas Faccio et al. (2001) argue that ownership concentration has a negative relation with dividends, indicating that there is a conflict of interest between majority and minority shareholder in firms with concentrated ownership. Jain and Chu (2014) investigate how country level variations affect the dividend payout policies. Using a sample across 32 countries, however, they find that firms pay higher dividends in countries with poor protection of minority shareholders. It is therefore hypothesized below that firms with higher levels of ownership concentration are associated with lower dividend payment.

H3a: The probability of firms paying dividends decreases if the level of ownership concentration is high.

H3b: The higher the level of ownership concentration, the smaller is the dividend payments.

Studies show the existence of family as the main shareholders in East Asian firms (Shleifer and Vishny 1997; La Porta et al. 2000a; Faccio et al. 2001). In the context of 
unifying ownership and control, family-controlled firms should have low agency costs due to the convergence of interest between principal and agent (Jensen and Meckling 1979). As argued by Gugler (2003), family-controlled firms have lower agency cost because of the closer control of managers by the family as dominant shareholder. However, Bertrand et al. (2000) claim that such family-controlled managers can act to maximize the family's wealth via tunneling or removing corporate resources through the intra-business transactions. Kim et al. (2005) further support this assertion. Using a sample of Korean firms, they provide evidence of a tunnelling behavior where the ownership structure distorts the allocation of internal funds in such a way to benefit the controlling shareholders. Such family-controlled firms are less protective to minority shareholders (Claessens et al. 2002). Faccio et al. (2001) point out the managers of such family-controlled firms can invest in low return projects as an indication of expropriation of minority shareholders. Hence, we conjecture that:

H4a: The probability of a firm to pay dividends decreases if the percentage of shares held by families is larger.

H4b: The larger the percentage of shares held by the families, the lower the dividends.

Numerous studies examine the motivation of the presence of foreign investors who are involved in stock market transactions. They can be classified into two broad categories: strategic investors with long term interest, and financial buyers with short term interest in holding firm stock. As strategic investors, they have the interest to increase firm performance by conducting controlling functions. Jeon et al. (2011) argue that foreign investors have more effective control and supervision due to their global standards and practices, which enable the firm to promote better governance practices. However, because of higher informational asymmetry compared to domestic investors, foreign investors require higher dividends to compensate for additional risk. Our next set of hypotheses then follows:

H5a: The probability of a firm to pay dividends increases if the percentage of shares held by foreign investors is larger.

H5b: The larger the percentage of shares held by foreign investors, the larger the dividends.

The dividends paid to the state-owned enterprises (SOE) as shareholders are crucial as they are one of the main government revenue sources. Because of the significant contribution to government revenues, the state as the main stockholder frequently targets the amount of dividend from SOEs to cover government budget. The typical characteristics of dividend policy of SOEs were investigated by some studies. Ben-Nasr (2015), using a sample of privatised firms from 43 countries, finds that government ownership enjoys a statistically significantly negative relation with dividends which is consistent with the prediction of agency theory. He also reports strong and robust evidence that higher degree of state ownership is associated with lower propensity to pay dividends. In India, Mishra and Narender (1996) point out that the Indian government set a minimum dividend declaration for SOEs unless the firms set a proposal for expansion or diversification. In their study in China, in which most of the publicly listed firms are government-owned at least partially, Wei and Varela (2003) find that there is a positive link between government ownership and dividends, where they report that the higher the ownership by government, the higher the 
dividends. The government expects SOEs to have high performance and pay a high dividend to the government. Thus, we expect that:

H6a: The probability of a firm to pay dividends increases if the percentage of shares held by the state is larger.

H6b: The larger the percentage of shares held by the state, the larger the dividends.

Agency theory argues that agency costs, as an effect caused by the divergence of interest between shareholders and managers, can be reduced by increasing dividend payment (Rozeff 1984). As a result, firms are forced to raise external financing from outside investors such as investment banks and other new investors which, in turn, can control the managers. Being monitored by the external investors, managers will have less possibility of utilizing firms' assets for their own benefits. Another alternative to reduce agency cost is that managers need to increase their share ownership to have better aligning of interest with shareholder (Jensen and Meckling 1976). The larger the proportion of stocks held by managers, the higher the dividends. However, having a higher proportion of stocks to control agency cost is not costless, because the managers will have less opportunity to diversify their wealth. Consequently, the managers will compensate the cost of the decreasing wealth due to the reduced opportunity to diversify their wealth to other media of investment by paying larger dividends. On the other hand, Schooley and Barney (1994) argue that executive stock ownership reduces agency cost and decreases dividends. However, until the ownership exceeds a specific point, higher stock ownership increases dividend payments. Our corresponding hypotheses are as follows:

H7a: The probability of a firm paying dividends increases if the percentage of shares held by managers is larger.

H7b: The larger the percentage of shares held by managers, the larger the dividends.

Allen et al. (2000) argue that institutional investors have good abilities to monitor firm management since they have a substantial amount of stocks in the firm. Tee et al. (2018) find that institutional ownership plays a major role in monitoring managers by reducing the positive association between politically connected firms and stock price crashes. The institutional investor can also force managers to impose a large penalty when the managers cut dividends (Leary and Michaely 2011). This means that institutional investors have an interest in the certainty of dividends as a return on their strategic investment in the firm. Institutional shareholders with significant control of firms require high dividends to mitigate the agency problem when managers use firms' free cash flows for their own benefits or use the cash to be invested in unprofitable projects, in line with Jensen's (1986) proposition of the agency cost hypothesis. In other words, institutional investors require higher dividends to mitigate agency costs of free cash flow. Gul and Kealey (1999) find no association between Korean Chaebol firms, who are characterized by concentrated institutional ownership, and dividends. However, Allen and Michaely (2003) argue that firms paying dividend attract more institutional investors and such investors can monitor managers better than individual investors. The better monitoring and control of institutional investors will reduce the agency problem that arises between managers and shareholders. In addition, the clientele dividend theory states that firms pay dividends because of different clients of shareholders. 
Firms having more institutional investors pay higher and more frequent dividends than firms with more individual investors. We therefore suggest that:

H8a: The probability of a firm to pay dividends increases if the percentage of shares held by institutional shareholders is larger.

H8b: The higher the institutional ownership in the firm, the larger the dividends.

\section{Data description and summary statistics}

\subsection{Data description}

Our sample comprises all non-financial firms listed in Indonesia Stock Exchange (IDX), for the period between 1995 and 2014. During this period of study, we intended to capture the dynamic situation of the Indonesian economy within which two economic shocks occurred namely, the 1997/1998 Southeast Asia economic crisis and the 2008 global financial crisis; hence, obtaining a better understanding of the dividend policy of IDX firms. We use Reuters Datastream to retrieve firms' financial information, while the data on stock ownership are obtained from the Indonesia Capital Market Directory (ICMD). ${ }^{3}$ From the original universe of all listed firms in IDX, we eliminate all financial firms in the sample following Fama and French (2001), and firms with observations less than four. ${ }^{4}$

As of December 2014, there were 502 firms listed in the IDX, but after removing financial firms (74 firms), missing and incomplete data, and eliminating firms carrying out IPO between 2012 and 2014, the final sample is a panel data set that contains 5386 firm-year observations representing 385 unique firms.

Table 1 represents the structure of the data used, containing, in panel A, the number of firms for each $\mathrm{N}$ years, while panel B provides the number of observations across each year from 1995 to 2014.

\subsection{Summary statistics}

Table 2 provides the descriptive statistics for the variables used in the study. The table shows that the average DPS is IDR64.27 with a standard deviation of IDR533.6. The maximum DPS is IDR12,000, which is equal to USD1 using the exchange rate in December 2014, suggesting that IDX firms pay low dividends relative to US firms. The average DIVTA is only 0.01 meaning that cash dividend paid for the period of 20 years equals $1 \%$ of assets with a maximum of $17.8 \%$. OverCash shows an average of $73.13 \%$ indicating that almost two-thirds of firm-year observations have cash over their optimal target ratio, whereas overinvestment shows an average of $38.26 \%$, meaning that less than half of IDX firm-year observations belong to the case of overinvestment.

The degree of concentration, measured by the square root of the five largest stockholders, indicates an average of $40.89 \%$, suggesting that most of the IDX firms are categorized

\footnotetext{
3 The Indonesia Capital Market Directory is an independent data provider in Indonesia.

4 During the sample period, new firms are including in the sample if they underwent an IPO process before 2011 to guarantee a minimum of four observations for each firm.
} 
A. Moin et al.

Table 1 Frequency of observations

\begin{tabular}{|c|c|c|c|}
\hline \multicolumn{2}{|l|}{ Panel A } & \multicolumn{2}{|c|}{ Panel B } \\
\hline N (years) & Number of firms & Year & $\begin{array}{l}\text { Number of } \\
\text { observations }\end{array}$ \\
\hline 1 & 0 & 1995 & 136 \\
\hline 2 & 0 & 1996 & 137 \\
\hline 3 & 0 & 1997 & 144 \\
\hline 4 & 11 & 1998 & 155 \\
\hline 5 & 13 & 1999 & 177 \\
\hline 6 & 18 & 2000 & 216 \\
\hline 7 & 29 & 2001 & 222 \\
\hline 8 & 32 & 2002 & 233 \\
\hline 9 & 15 & 2003 & 236 \\
\hline 10 & 10 & 2004 & 256 \\
\hline 11 & 20 & 2005 & 265 \\
\hline 12 & 4 & 2006 & 282 \\
\hline 13 & 10 & 2007 & 313 \\
\hline 14 & 7 & 2008 & 342 \\
\hline 15 & 35 & 2009 & 360 \\
\hline 16 & 21 & 2010 & 374 \\
\hline 17 & 10 & 2011 & 384 \\
\hline 18 & 6 & 2012 & 384 \\
\hline 19 & 4 & 2013 & 385 \\
\hline 20 & 140 & 2014 & 385 \\
\hline Total firms & 385 & Total & 5386 \\
\hline
\end{tabular}

The table provides the distribution of observations for each year across the sample period. Panel A reports the number of firms for each year. Firms considered in the study are those having data for at least four consecutive years. The data are retrieved from Datastream and Indonesian Capital Market Directory for the period between 1995 and 2014. Panel B reports the number of observations for each year

into concentrated ownership. In addition, by examining the maximum value of concentration, some shareholders have controlled nearly $100 \%$ of the stocks.

By comparing the absolute percentage of stock ownership, foreign ownership is the highest, followed by State, managerial, family and institutional ownership. Foreign ownership shows the maximum $92 \%$, with average $12.76 \%$. The figure suggests that foreign investment has been a significant amount, particularly after Indonesia liberalized its capital market after the financial crisis 1997/1998, for which foreign investors were allowed to invest up to $99 \%$ of IDX's equity.

The average percentage of shares held by families (Family1) is relatively low, that is, only $3.08 \%$ with a maximum of $66 \%$. However, the low percentage is due to the method of measurement, which is based on immediate ownership, whereas the typical family ownership of Indonesian firms is that family commonly use cross-holdings and indirect ownership.

Table 2 shows that state ownership (State1) has an average 1.82\%, indicating that the government invests only in firms categorized as SOEs. In contrast, the State has no equity stake in private firms listed in IDX, except in a joint venture between Jakarta 
Table 2 Summary statistics

\begin{tabular}{|c|c|c|c|c|c|}
\hline Variable & $\mathrm{N}$ & Mean & SD & Minimum & Maximum \\
\hline Dummy dividend & 5331 & 0.5003 & 0.500 & 0 & 1 \\
\hline DPS (IDR) & 5331 & 64.2700 & 533.60 & 0 & 12,000 \\
\hline DIVTA & 5331 & 0.0100 & 0.0270 & 0 & 0.1780 \\
\hline Excess cash & 5331 & -0.0005 & 0.986 & -3.0913 & 1.9587 \\
\hline OverCash & 5331 & 0.7313 & 0.4433 & 0 & 1 \\
\hline Excess investment & 5331 & -0.0092 & 0.7974 & -3.6167 & 1.3333 \\
\hline Overinvestment & 5331 & 0.3826 & 0.4932 & 0 & 1 \\
\hline Concentration & 4823 & 0.4089 & 0.2286 & 0.10 & 0.9998 \\
\hline Family1 & 3047 & 0.0308 & 0.1048 & 0 & 0.6600 \\
\hline Family2 & 3047 & 0.0479 & 0.2136 & 0 & 1 \\
\hline Family3 & 3047 & 0.0279 & 0.1646 & 0 & 1 \\
\hline Foreign1 & 3023 & 0.1276 & 0.2435 & 0 & 0.92 \\
\hline Foreign2 & 3023 & 0.1404 & 0.3474 & 0 & 1 \\
\hline Foreign3 & 3023 & 0.1146 & 0.3185 & 0 & 1 \\
\hline State1 & 3023 & 0.0182 & 0.1055 & 0 & 0.9 \\
\hline State2 & 3023 & 0.0347 & 0.1830 & 0 & 1 \\
\hline Managerial1 & 3673 & 0.0360 & 0.1077 & 0 & 0.89 \\
\hline Managerial2 & 3673 & 0.0608 & 0.2391 & 0 & 1 \\
\hline Managerial3 & 3673 & 0.0388 & 0.1931 & 0 & 1 \\
\hline Institutional & 3023 & 0.0037 & 0.0190 & 0 & 0.13 \\
\hline Size (million IDR) & 5331 & 4000 & 10,700 & 554 & 233,000 \\
\hline Growth & 4857 & 0.1979 & 0.4263 & -0.7507 & 2.3491 \\
\hline MVBV & 4669 & 1.4313 & 1.0210 & 0.3141 & 6.6192 \\
\hline Free cash flow & 5142 & 0.1607 & 0.2416 & -0.3639 & 1.2859 \\
\hline Leverage & 5183 & 0.2938 & 0.2301 & 0 & 0.8862 \\
\hline Tangibility & 5196 & 0.3971 & 0.2439 & 0.0022 & 0.9222 \\
\hline Fixed charges & 5036 & 0.0279 & 0.0323 & 0 & 0.1851 \\
\hline Profitability & 5198 & 0.0267 & 0.1157 & -0.4967 & 0.3608 \\
\hline Risk & 4657 & 0.8089 & 0.5928 & -0.612 & 2.4530 \\
\hline Age & 5331 & 34.119 & 16.8070 & 4 & 108 \\
\hline
\end{tabular}

The study uses 385 firms with 5386 firm-year observations for the period between 1995 and 2014. All data are from Datastream and Indonesian Capital Market Directory. The values of all financial variables are reported in the Indonesian Rupiah (IDR). All ownership related variables represent the fractions and are in decimal values. Size is reported in million rupiahs and age is in the year. The nonratio variables (i.e., DPS, Age, Size) are logarithmic-transformed for the regression analyses. The definitions of all variables are provided in the "Appendix"

governmental province and a property firm. This study shows that there are 11 SOEs listed in IDX, consisting of pharmacy (2 firms), energy (1), steel (1), telecommunication (1), construction (4), and mining industries (2). As many as 15 SOEs undertook IPO between 1995 and 2014; four of them are banks. This means that all SOEs listed in the capital market occurred within the period. 


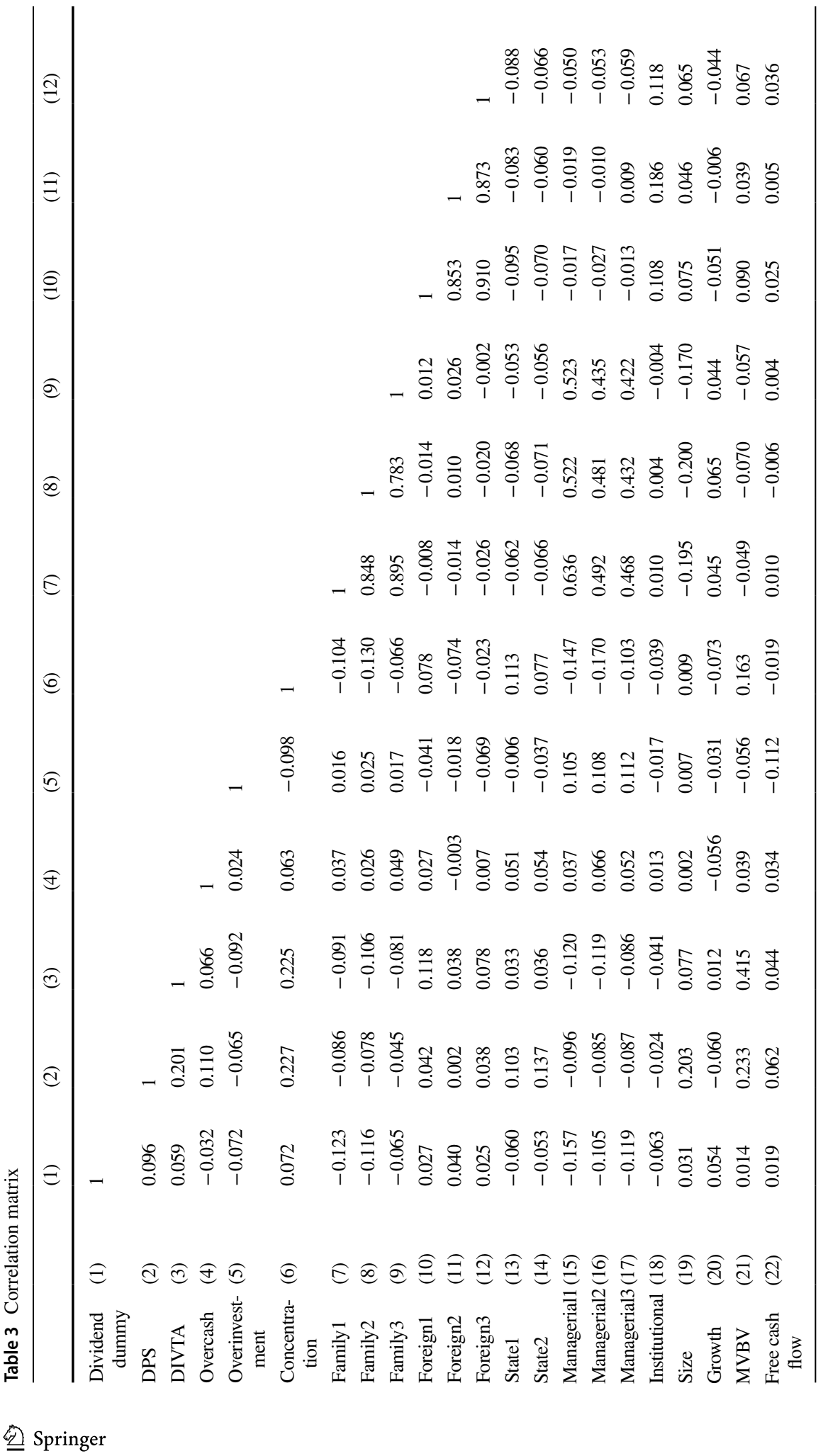




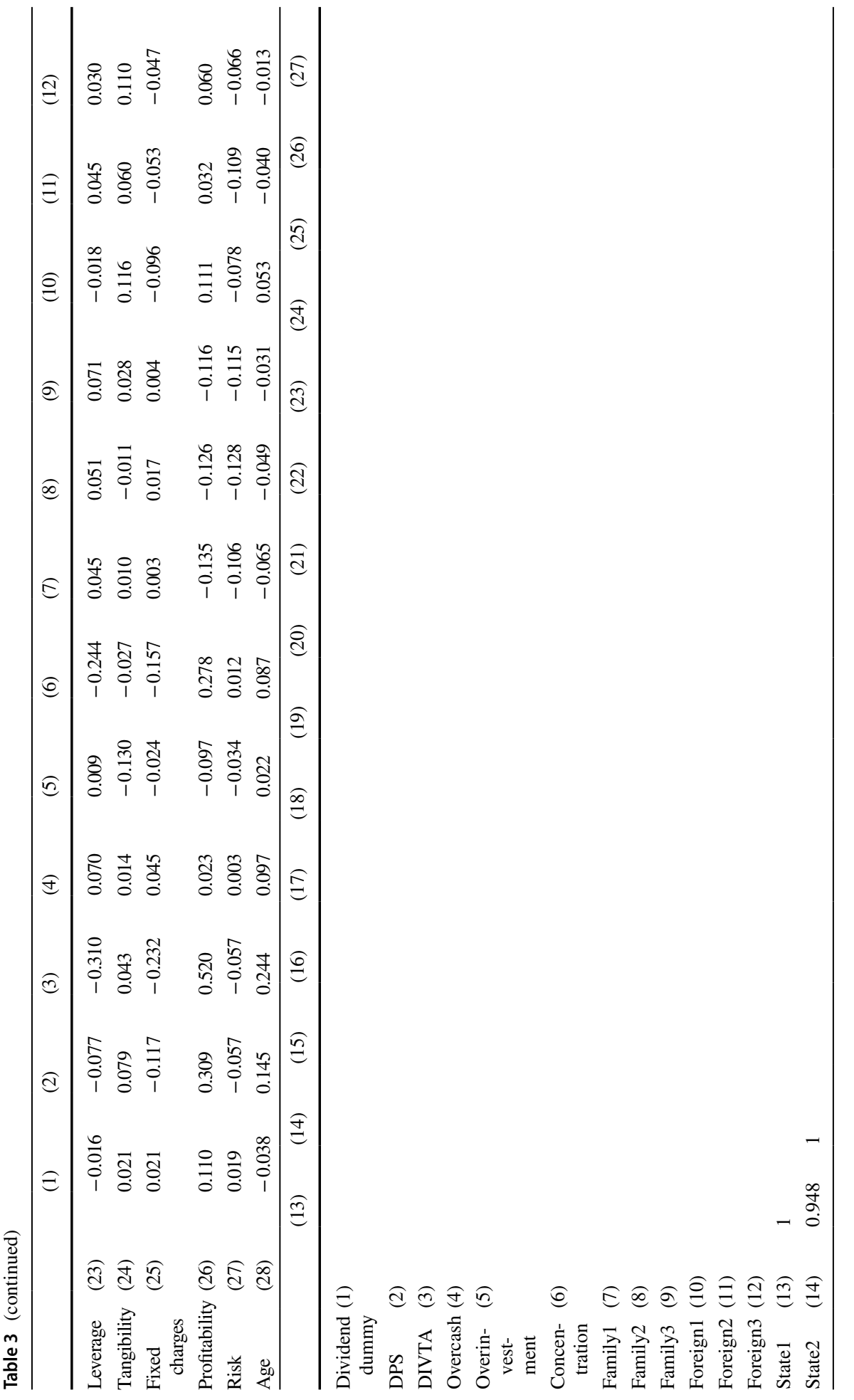




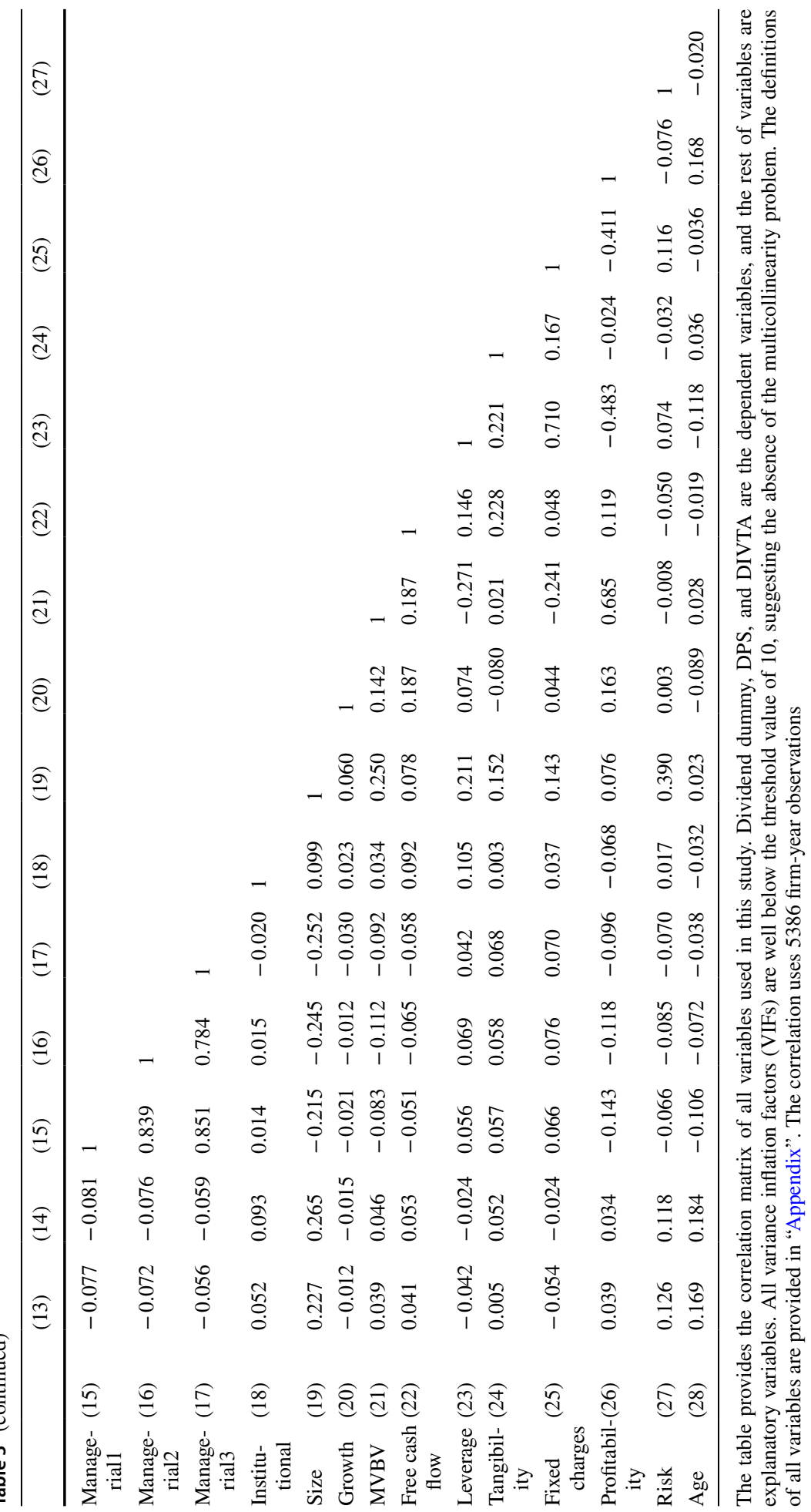


Managerial ownership (Managerial1) shows an average $3.6 \%$ with maximum $89 \%$. Many of the IDX firms are family dominated firms with one or more manager-related family; managers could use indirect ownership via cross holdings ownership. The average percentage of institutional ownership is the lowest one with only $0.37 \%$, and the maximum is $13 \%$. Financial institutions such as insurance and pension funds as their portfolio interest commonly own the institutional shares. Regarding the value of assets, firm size indicates a substantial book value of assets due to the high denomination of IDR currency but low exchange rate. The average firm size is IDR4 billion, with a minimum of IDR554 million and maximum of IDR233 trillion.

Table 3 provides the correlation matrix for the variables used in this study. Higher correlations occur in ownership variables because of the classification. For instance, variables within the family group, such as family 1 , family 2 , and family 3 , have high coefficient correlations. The high correlation coefficients also occur for groups of variables of foreign, state, and managerial ownership. For the purposes of regression analysis, however, variables with high correlation are not included in the model.

\subsection{Mean difference tests}

The test is intended to statistically analyze whether the two groups (dividend payers and non-dividend payers) are significantly different. Table 4 presents the values of mean, median (in brackets under the payer and non-payer columns), mean difference, and the statistical $t$ test and Wilcoxon signed-rank test (in brackets) for the variables used in this study. Columns 2 and 3 show the mean of each variable for dividend payers and non-dividend payers, while the mean differences are presented in column 4 . The positive sign indicates that the mean of dividend payers for a given variable is larger than that of non-dividend payers.

Table 4 shows that mean difference is highly significant at the 5\% and $1 \%$ levels in almost all variables in which dividend payers have a higher mean than non-dividend payers. For variables of family1, State1, leverage, tangibility, and fixed charges, the mean of dividend payers is less than that of non-dividend payers. We find the average percentage of ownership, for family1 and managerial1, of non-dividend payers is larger than those of dividends-payers. However, it is normal for firms to have higher leverage and fixed charges to become non-dividend payers. This suggests that debt and fixed charges reduce the probability and the intensity of firms paying dividends.

\section{Empirical methodology}

\subsection{Baseline models}

To examine the likelihood of firms paying dividends and to analyze the differential probability for capturing the propensity to pay dividends, we estimate the following probit model:

$$
\begin{aligned}
& \operatorname{Prob}\left(Y_{i, t}>0\right)=\alpha+\beta_{1} \text { OverCash }_{i, t}+\beta_{2} \text { Overinvestment }_{i, t}+\beta_{3} \text { Concentration }_{i, t} \\
& \quad+\psi_{m} \sum_{m=1}^{5} \text { Ownership }_{i, t}+\gamma_{n} \sum_{n=1}^{10} \text { Control Variable }_{i, t}+\pi_{p} \sum_{p=1}^{19} \text { Year }_{p}+\tau_{q} \sum_{q=1}^{6} \text { Industry }_{q}+\varepsilon_{i, t}
\end{aligned}
$$


Table 4 Characteristics of dividends payers and non-payers groups

\begin{tabular}{|c|c|c|c|c|}
\hline & Payer & Non-payer & Mean difference & $\begin{array}{l}t \text { test (Wilcoxon } \\
\text { signed-rank test) }\end{array}$ \\
\hline Overcash & $\begin{array}{l}0.409 \\
(1)\end{array}$ & $\begin{array}{l}0.321 \\
(1)\end{array}$ & 0.061 & $\begin{array}{l}7.564 * * * \\
(7.536)^{* * * *}\end{array}$ \\
\hline Overinvestment & $\begin{array}{l}0.304 \\
(1)\end{array}$ & $\begin{array}{l}0.277 \\
(1)\end{array}$ & 0.019 & $\begin{array}{l}2.571 * * * \\
(2.571)^{* *}\end{array}$ \\
\hline Concentration & $\begin{array}{l}0.417 \\
(0.366)\end{array}$ & $\begin{array}{l}0.389 \\
(0.332)\end{array}$ & 0.029 & $\begin{array}{l}7.977 * * * \\
(5.916) * * *\end{array}$ \\
\hline Family1 & $\begin{array}{l}0.377 \\
(0.32)\end{array}$ & $\begin{array}{l}0.437 \\
(0.5)\end{array}$ & -0.060 & $\begin{array}{l}-2.140 * * \\
(-2.384)^{* *}\end{array}$ \\
\hline Foreign 1 & $\begin{array}{l}0.535 \\
(0.510)\end{array}$ & $\begin{array}{l}0.474 \\
(0.450)\end{array}$ & 0.061 & $\begin{array}{l}3.700 * * * \\
(2.764) * * *\end{array}$ \\
\hline State1 & $\begin{array}{l}0.548 \\
(0.55)\end{array}$ & $\begin{array}{l}0.697 \\
(0.69)\end{array}$ & -0.149 & $\begin{array}{l}6.795 * * * \\
(7.502) * * *\end{array}$ \\
\hline Managerial1 & $\begin{array}{l}0.444 \\
(0.348)\end{array}$ & $\begin{array}{l}0.438 \\
(0.392)\end{array}$ & 0.005 & $\begin{array}{l}-2.906 \\
(-0.258)\end{array}$ \\
\hline Institutional & $\begin{array}{l}0.598 \\
(0.6)\end{array}$ & $\begin{array}{l}0.436 \\
(0.5)\end{array}$ & 0.162 & $\begin{array}{l}0.195 \\
(0.935)\end{array}$ \\
\hline Size (Ln Total Assets) & $\begin{array}{l}17.555 \\
(0.51)\end{array}$ & $\begin{array}{l}16.290 \\
(0.435)\end{array}$ & 1.265 & $\begin{array}{l}2.336 * * * \\
(5.761)^{* * * *}\end{array}$ \\
\hline Growth & $\begin{array}{l}0.269 \\
(0.239)\end{array}$ & $\begin{array}{l}0.225 \\
(0.219)\end{array}$ & 0.044 & $\begin{array}{l}1.887 * * \\
(9.649) * * *\end{array}$ \\
\hline MVBV & $\begin{array}{l}1.567 \\
(1.276)\end{array}$ & $\begin{array}{l}1.447 \\
(1.156)\end{array}$ & 0.120 & $\begin{array}{l}8.792 * * * \\
(8.644)^{* * *}\end{array}$ \\
\hline Free cash flow & $\begin{array}{l}0.287 \\
(0.258)\end{array}$ & $\begin{array}{l}0.264 \\
(0.261)\end{array}$ & 0.023 & $\begin{array}{l}5.847 * * * \\
(10.140) * * *\end{array}$ \\
\hline Leverage & $\begin{array}{l}0.391 \\
(0.357)\end{array}$ & $\begin{array}{l}0.445 \\
(0.428)\end{array}$ & -0.054 & $\begin{array}{l}-5.886 \\
(-2.044)^{* *}\end{array}$ \\
\hline Tangibility & $\begin{array}{l}0.424 \\
(0.388)\end{array}$ & $\begin{array}{l}0.565 \\
(0.485)\end{array}$ & -0.141 & $\begin{array}{l}-3.492 \\
(-1.161)\end{array}$ \\
\hline Fixed charges & $\begin{array}{l}0.369 \\
(0.299)\end{array}$ & $\begin{array}{l}0.399 \\
(0.336)\end{array}$ & -0.030 & $\begin{array}{l}-5.472 \\
(-0.239)\end{array}$ \\
\hline Profitability & $\begin{array}{l}0.332 \\
(0.311)\end{array}$ & $\begin{array}{l}0.096 \\
(0.165)\end{array}$ & 0.236 & $\begin{array}{l}23.516 * * * \\
(25.037)^{* * *}\end{array}$ \\
\hline Risk & $\begin{array}{l}0.875 \\
(0.844)\end{array}$ & $\begin{array}{l}0.832 \\
(0.791)\end{array}$ & 0.044 & $\begin{array}{l}5.600 * * * \\
(7.998) * * *\end{array}$ \\
\hline Age & $\begin{array}{l}35.417 \\
(34)\end{array}$ & $\begin{array}{l}27.954 \\
(27)\end{array}$ & 7.463 & $\begin{array}{l}7.875 * * * \\
(4.980)^{* * *}\end{array}$ \\
\hline
\end{tabular}

The table compares the characteristic of dividend paying firms (Payer) with non-dividend paying firms (Non-payer) by reporting the mean and median (in brackets under each variable for the Payer and NonPayer columns). Also, we report the mean difference, the $t$-test and the Wilcoxon signed rank-test (in brackets) of dividend paying and non-dividend paying firms. ***, ** and * indicate statistical significance at the $0.01,0.05$ and 0.10 levels, respectively. The definitions of all variables are provided in "Appendix"

where " $\operatorname{Prob}\left(Y_{i, t}>0\right)$ " indicates a firm's likelihood to pay dividends (i.e., $Z_{i, t}=1$ if $Y_{i, t}>0$ ); $Y_{i, t}$ is a measure of the propensity to pay dividends by firm $i$ in year $t ; \beta \mathrm{s}, \psi \mathrm{s}, \gamma \mathrm{s}, \pi \mathrm{s}$ and $\tau \mathrm{s}$ 
are estimable slope parameters; $\alpha$ is the constant term. Ownership variables consist of (i) family; (ii) foreign; (iii) state; (iv) managerial; and (v) institutional. Following the previous literature on the decision to pay dividends and the determinants of dividend payout, we include a number of control variables in the decision to pay a dividend, that is, profitability; leverage (Hu and Kumar 2004); free cash flow (Eisdorfer et al. 2015); size and market to book value (Fuller and Blau 2010); growth, size, risk, and age (Twu 2012); and tangibility and fixed charges (Aivazian et al. 2003). ${ }^{5}$

Following previous studies (e.g., Opler et al. 1999; Harford et al. 2008; Jiang and Lie 2016; El Kalak and Tosun 2019), for each year, we estimate the excess cash for firm $i$ as the residual of the following cross-sectional regression:

$$
\begin{aligned}
\text { Cash }_{i}= & \alpha+\beta_{1} \text { Free Cash Flow }_{i}+\beta_{2} \text { Leverage }_{i}+\beta_{3} \text { MVBV }_{i}+\beta_{4} \text { Size }_{i}+\beta_{5} N W C_{i} \\
& +\beta_{6} \text { CAPEX }_{i}+\beta_{7} \text { Payout Ratio }_{i}+\beta_{8} R \& D_{i}+\beta_{9} \text { Age }_{i}+\varepsilon_{i}
\end{aligned}
$$

where Cash is the ratio of cash to total assets; $R \& D$ is the research and development expenses over sales ratio; $N W C$ is the ratio of net working capital minus cash over total assets; CAPEX is capital expenditure over total assets; Payout Ratio is the sum of cash dividend divided by total assets. In this setting, the residual $\varepsilon_{\mathrm{i}}$ is used as a proxy for firm $i$ 's excess cash in a given year. A positive (negative) residual indicates that the firm hoards more (less) cash than it needs for its normal operational activities and investments during that year. For the purpose of our study, we define OverCash as a dummy variable which is 1 when the residual is positive, which indicates that cash is in excess of normal operations and investments, and 0 otherwise.

As for the estimation of overinvestment, we use the same set of variables used by Richardson (2006) to estimate the residual. However, we depart from the method of Richardson (2006) by following previous literature, such as Chen et al. (2016) and Guariglia and Yang (2016), where we use a panel data regression with fixed effects to estimate the deviation investment as the residual of Eq. (3). The use of panel data estimation allow for a partial adjustment mechanism to control for unobserved factors not included among regressors, where the residual $\varepsilon_{i}$ is used as a proxy for firm i's deviation investment (excess investment) in a given year. A positive (negative) residual indicates that the firm over (under) invests during that year. For the purpose of our study, we define Overinvestment as a dummy variable that equals 1 when the residual is positive, which indicates that the firm overinvest in that particular year, and 0 otherwise. ${ }^{6}$

$$
\text { New } \text { Investment }_{i, t}=\alpha+\beta_{1} \text { New } \text { Investment }_{i, t-1}+\beta_{2} \text { Other Controls } \text { Citt-1 }_{i}+\eta_{i}+\phi_{t}+\varepsilon_{i, t}
$$

\footnotetext{
${ }^{5}$ Definition of variables is provided in the Appendix (Table 10).

${ }^{6}$ In an untabulated results, to verify the robustness of our estimation of overinvestment, we use the following three methods: (i) we implement Richardson's (2006) set of explanatory variables using the system GMM estimator (Blundell and Bond 1998). The system GMM estimator is used to take into account unobserved firm heterogeneity and the possible endogeneity and mis-measurement problems of the regressors. This method has been used by Antoniou et al. (2008), Guariglia and Yang (2016) and Ding et al. (2016); (ii) we use Bates (2005) approach that determines whether firms overinvest by comparing the capital expenditure ratios of each firm operating in a given industry in a given year with the median ratio of all firms operating in the same industry during that year. If the difference is positive (negative), then this approach assumes the firm overinvested (underinvested); (iii) following Ding et al. (2016) we define overinvestment when the investment ratio of a sample firm in a given industry and year is in excess of the median value of all firms operating in the same industry in that year. Our results remain qualitatively robust for the use of these different methods.
} 
where NewInvestment $=$ Capital Expenditure + Research and Development $(\mathrm{R} \& \mathrm{D})$ Depreciation and Amortization. OtherControls include Growth Opportunities, Leverage, Free Cash Flow, Cash, Age, Size, and Stock returns. $\eta_{\mathrm{i}}$ represents firm fixed effects while $\phi_{\mathrm{t}}$ denotes year fixed effects.

Furthermore, to examine the intensity of paying dividends we run model (1) using the OLS method while changing the dependent variable $Y_{i t}$ to capture the level of dividends by using two measures namely, dividends per share (DPS) and dividends over total assets (DIVTA). Table 10 in the "Appendix" lists all the variables used in the study as well as specifying their definitions and expected signs.

\subsection{Robustness tests}

The challenge we face when attempting to identify a causal effect of overcash, overinvestment, and ownership-related variables on the firm's dividend policies is the possibility of omitted variable bias. The section addresses these endogeneity concerns in the following two different ways. First, we employ an instrumental variable approach namely the generalized method of moments with instrumental variables (IV-GMM). Second, we use the Heckman's two-step estimation procedures to consider sample selection bias having potential determinants in affecting dividend decisions.

\subsubsection{The IV-GMM estimation method}

Antoniou et al. (2008) suggest that the use of OLS estimation as shown in Eq. 1 produces biased coefficients because time-specific effect $\left(\mu_{i}\right)$ is unobservable, and it correlates with other regressors. In addition, the OLS strictly assumes that all of the explanatory variables are exogenous. To overcome the problem, we use fixed effects estimation and IV-GMM to test the robustness of estimation by treating ownership-related explanatory variables as endogenous. In a model with endogenous variables, Arellano and Bond (1991) suggest the use of the instrumental variables (IV) technique by generating lagged values of variables. We use internal instruments for the factors related to corporate ownership structure by using their lags up to three periods.

The IV-GMM requires that the correlation between an instrumental variable $(Z)$ and error $(\eta)$ to be orthogonal, or $\operatorname{Cov}(Z, \eta)=0$, and the covariance between an instrumental and endogenous explanatory variable $(S)$ is different from zero, or $\operatorname{Cov}(S, Z) \neq 0$. Therefore, there will be two tests regarding the endogeneity problem. First, the Hausman test is used to identify whether a potentially exogenous variable is actually endogenous. Second, the Sargan-Hansen test is used to test the null hypothesis stating that the overidentifying restrictions are valid.

\subsubsection{Heckman's two-step estimation procedure}

Heckman's two-step technique is commonly used to investigate a firm's decision on dividend policy. It consists of two steps: (i) the propensity to pay dividends, and (ii) the intensity to dividend payments. The propensity to pay dividends examines the likelihood of firms paying cash dividends. The intensity of paying dividends is measured by the amount of dividends paid. The OLS model estimation below is a censored regression model which can be used for Heckman's two-step estimation procedures. 


$$
\begin{aligned}
\text { E }_{\left(\text {DPS }_{i, t}, \text { DIVTA }_{i, t} \mid Z_{i, t}=1\right)=} & \alpha+\beta_{1} \text { OverCash }_{i, t}+\beta_{2} \text { Overinvestment }_{i, t}+\beta_{3} \text { Concentration }_{i, t} \\
& +\beta_{4} \lambda_{i, t}+\psi_{m} \sum_{m=1}^{5} \text { Ownershi }_{i, t}+\gamma_{n} \sum_{n=1}^{10} \text { Control Variable }_{i, t} \\
& +\pi_{p} \sum_{p=1}^{19} \text { Year }_{p}+\tau_{q} \sum_{q=1}^{6} \text { Industry }_{q}+v_{i, t}
\end{aligned}
$$

where " $E\left(D P S_{i t}, D I V T A_{i t} \mid \mathrm{Z}_{\mathrm{i}, \mathrm{t}}=1\right)$ " indicates the expected intensity level if firms pay dividends with DPS and DIVTA as dependent variables; $\beta \mathrm{s}, \psi \mathrm{s}, \gamma \mathrm{s}, \pi \mathrm{s}$ and $\tau \mathrm{s}$ are estimable slope parameters; $v_{\text {it }}$ is the idiosyncratic error term that is jointly normally distributed giving zero means and the correlation of rho $(\rho)$; lambda $(\lambda)$ is the inverse Mill's ratio obtained for the purpose of selection correction in which a significant Mill's ratio implies the presence of the sample selection bias.

\section{Main findings}

\subsection{The propensity to pay dividends}

Table 5 presents the determinants of firms paying dividends using the probit estimations. Panel A reports the raw coefficient estimation, and Panel B reports the marginal effects. The results of regression in Model1 reveal that the propensity to pay dividends is positively related to overcash (statistically significant at the 5\% level), suggesting that firms with overcash have a higher probability of paying dividends. The finding supports Hypothesis 1a stating that the probability of a firm paying dividends increases if a firm is over-cashed. Holder et al. (1998) find that overcash has a positive relation with dividends. Further, the relation between overinvestment and the propensity to pay dividends is negative and significant as shown in model 3. This indicates that overinvestment is a strong determinant of a firm's decision to pay or not to pay dividends. The result supports Hypothesis 2a stating that the probability of a firm paying dividends decreases if a firm is overinvested. This is consistent with Richardson's (2006) study showing that firms with overcash tend to overinvest, which results in lower dividend payments.

The propensity to pay dividends has a significant and negative link with the percentage of family ownership, suggesting that the larger the family ownership, the lower the likelihood of firms paying dividends. The finding is consistent with our Hypothesis 4a stating that families expropriate the firm's cash for their own interest by decreasing the probability of paying dividends to shareholders. The finding is also consistent with the results of the $t$-test and Wilcoxon test as shown in Table 4, suggesting that the higher the family ownership, the lower the probability of a firm paying dividends. However, model 1 also exhibits that managerial ownership is positively and significantly related to the propensity of paying dividends; the larger the managerial ownership, the higher the likelihood of a firm paying dividend. In model 1, when family ownership and managerial ownership are simultaneously regressed in a single model, their coefficients are significant but have different signs. This indicates that managers and families have different interests regarding dividend payment. The finding supports the agency cost theory, which asserts that the principal and agent are divergent regarding their interests. 


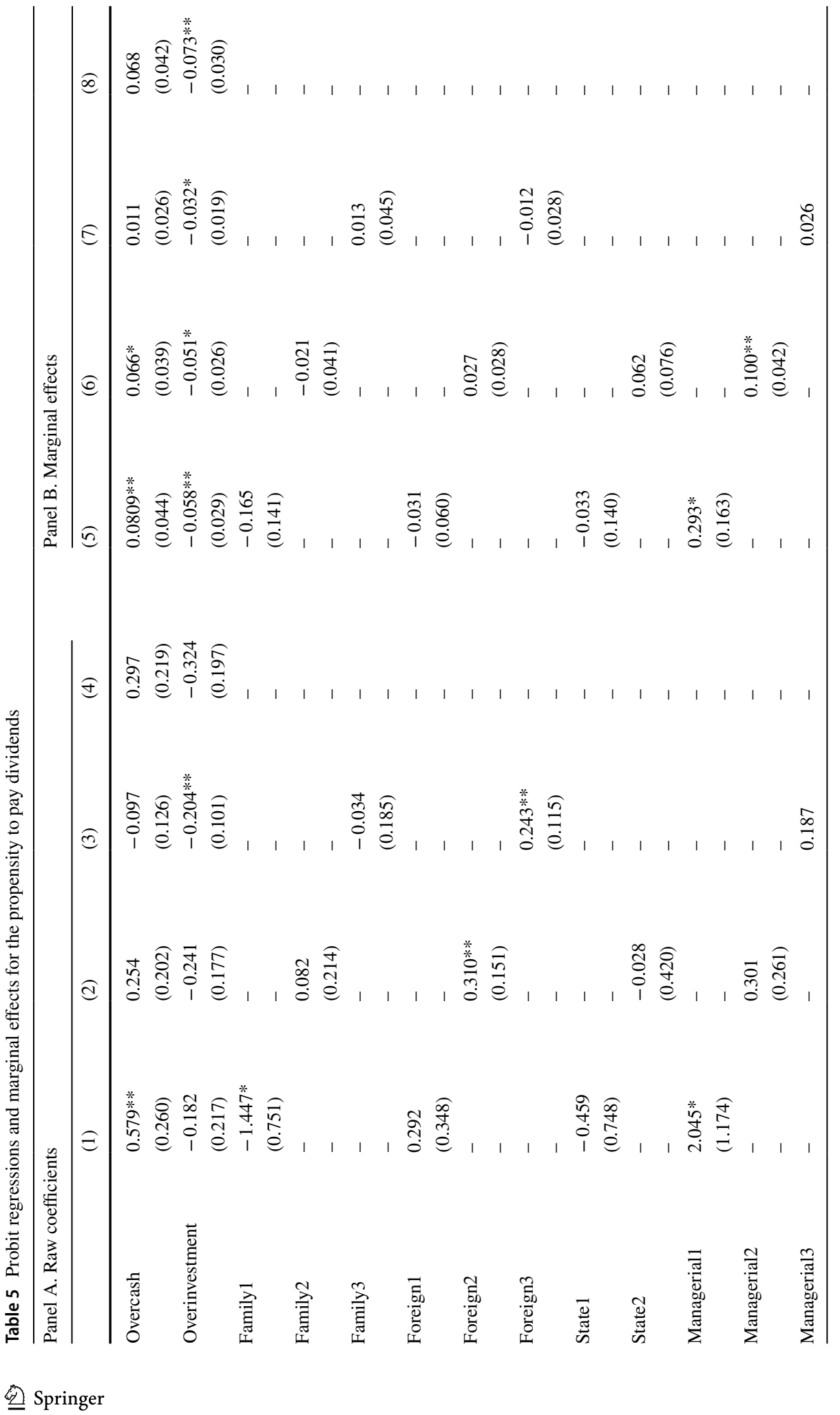




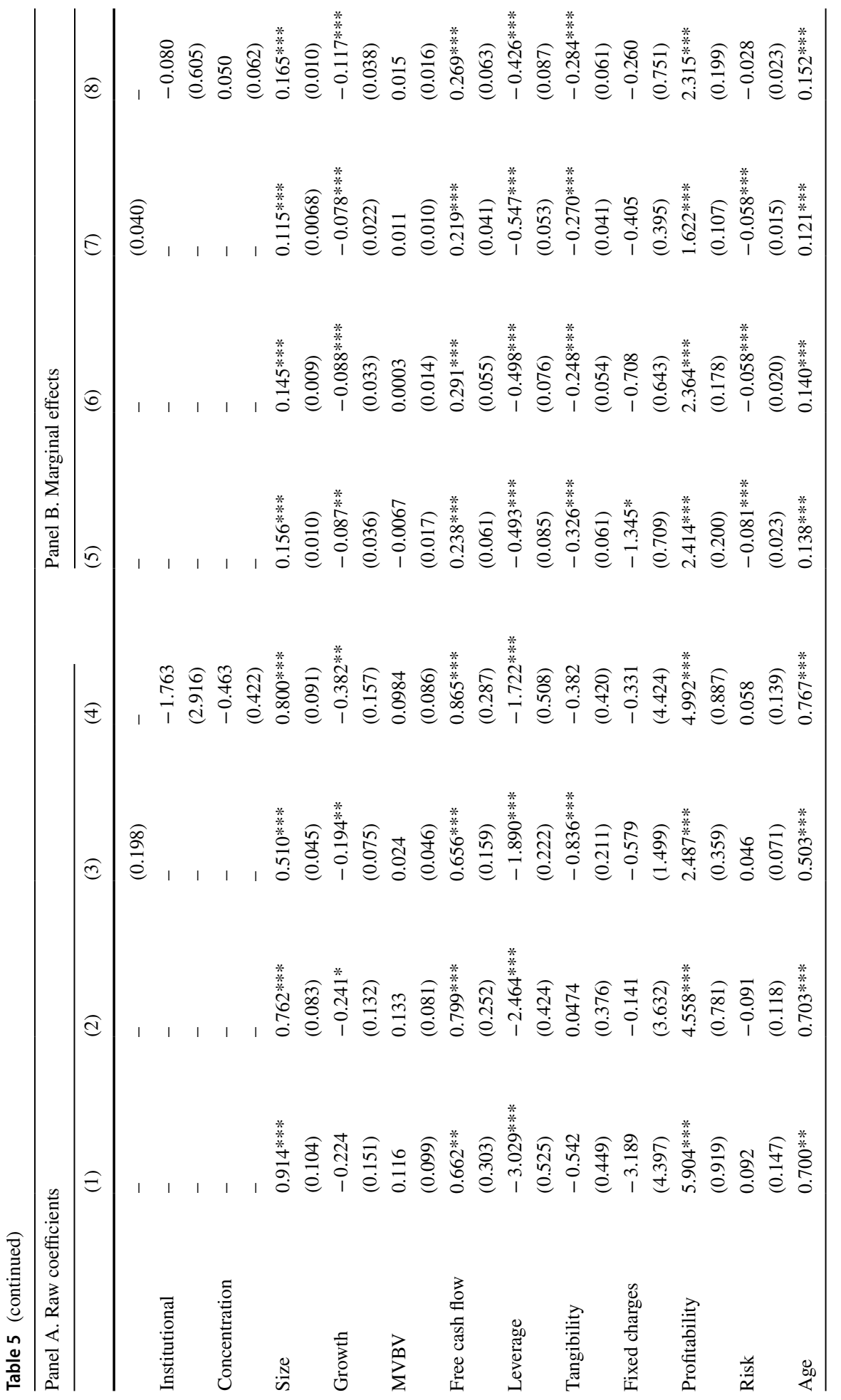




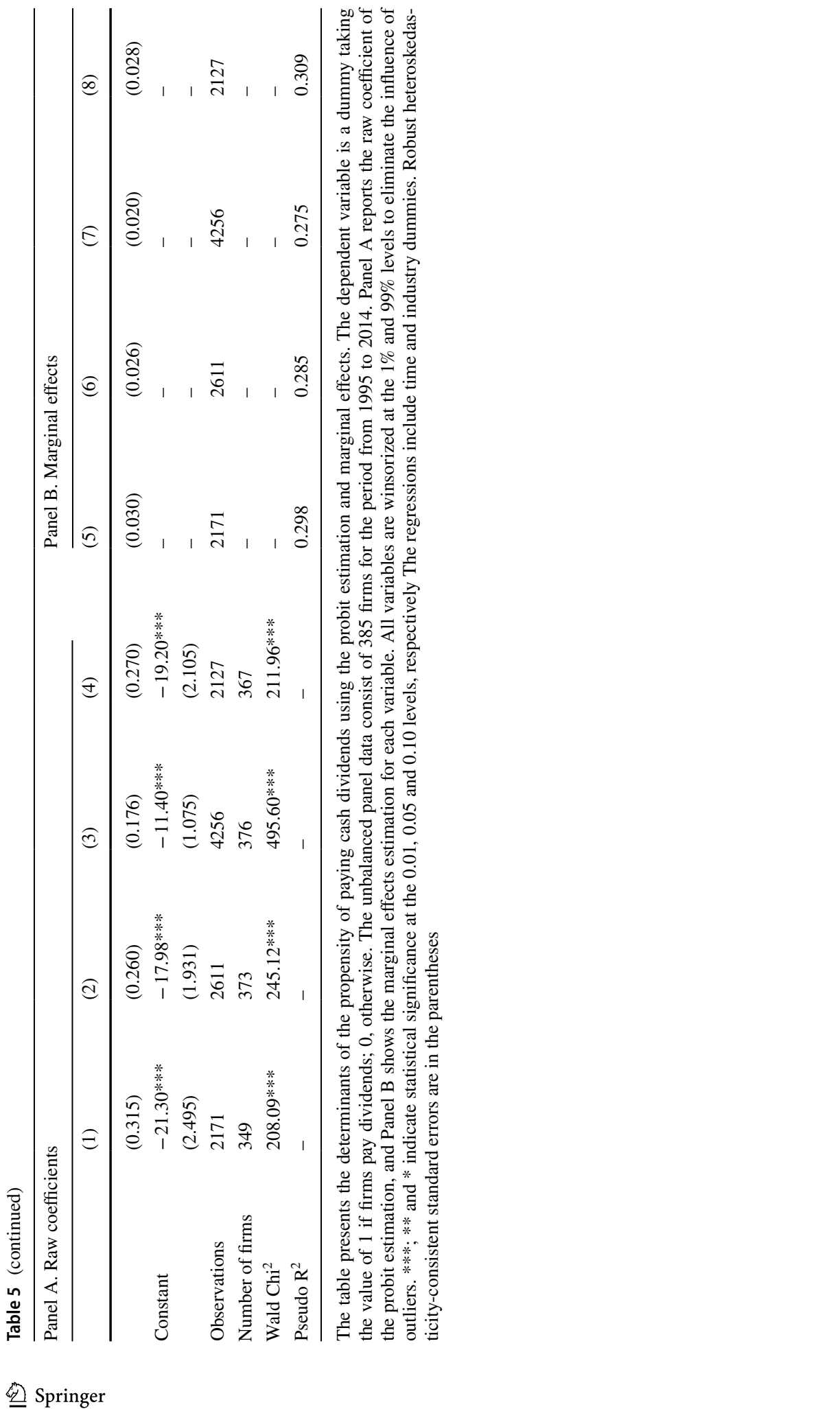


In Panel A, foreign2 and foreign3 are positively and significantly associated with the propensity of the firm paying dividends (models 2 and 3). These results demonstrate that the larger the proportion of foreign ownership, the higher the propensity of firms paying dividends. In other words, this finding indicates that the probability of a firm paying dividends increases if the percentage of shares held by independent investors is larger. This can also mean that foreign investors require a higher dividend to compensate higher country risk (Jeon et al. 2011) as predicted in Hypothesis 5a. In addition, other types of ownership such as state and institutional indicate a weak relation with the propensity to pay dividends.

Panel B reports the marginal effects of explanatory variables on the propensity of paying dividends. The coefficients of overcash (models 5 and 6) are strongly related to the propensity to pay dividends. Their significant coefficients explain that one standard deviation increase (i.e., $44.33 \%$, see Table 2 ) in overcash raises the probability of paying dividends by $8.1 \%$ and $6.6 \%$, respectively.

In Panel B, the marginal effects for overinvestment are negative and statistically significant. The effect in model 5 explains that a one standard deviation increase in overinvestment (i.e., $49.32 \%$ ) reduces the probability of paying dividends by $5.8 \%$. Examining the marginal effects among these ownership variables, only managerial ownership has a strong relation with the propensity to pay dividends. For the other variables: Managerial 1 and Managerial2 (models 5 and 6) showing a significant relation with the propensity to pay dividends, their marginal effects suggest that the likelihood of paying dividends increases by $29.3 \%$ and $10 \%$ as a response to one standard deviation increase (i.e., $10.77 \%$ and $23.91 \%$ ), respectively. In addition, the level of concentration has a statistically weak relation with the propensity to pay dividends. Finally, the lower parts of Panel B show the coefficients of determination, which explain the aggregate test of the variables of the model. ${ }^{7}$

\subsection{The level of dividend payments: DPS as dependent variable}

Table 6 exhibits the regression results using three estimation methods: OLS, IV-GMM, and FE for different endogenous ownership variables. Under OLS, overcash has a strong relation with DPS for all ownership types. On the other hand, overinvestment is statistically significant only when ownership structure is based on managerial ownership. Further, ownership concentration is significant in almost all models with a positive sign, indicating that the higher the level of ownership concentration, the larger the level of dividends. The results thus support our hypothesis $(H 3)$. One possible explanation for this finding is that the ownership structure of the IDX firms is dominated by the largest five shareholders with full control rights on management's decision making and these large shareholders tend to make larger dividend payments rather than accumulating more cash. Our results support the findings of Kim et al. (2013) who report that controlling shareholders in Korean firms have strong influence on payout policies. However, our finding contradicts those indicated by previous studies that large shareholders pay lower dividends (e.g., Shleifer and Vishny 1997; Faccio et al. 2001).

Family and state ownership have weak relations with the level of dividend payments. However, foreign, managerial and institutional ownership have strong links with dividends,

\footnotetext{
7 In untabulated results, we re-estimate our main model in Eq. (1) where we have divided our sample according to firm size (large vs. small firms based on the median values) and industry category (manufacturing vs. non-manufacturing firms). The results remain qualitatively unchanged.
} 


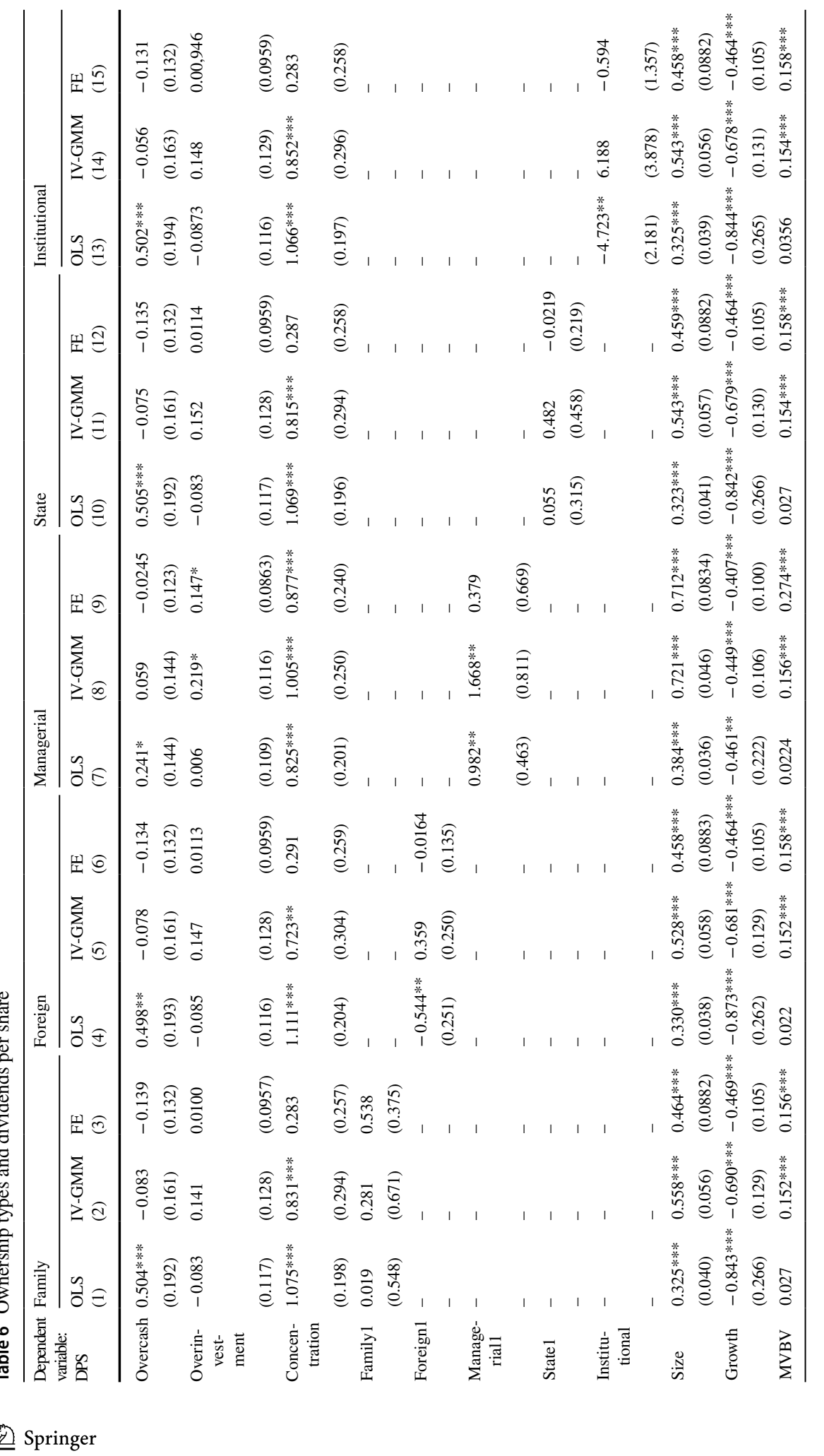




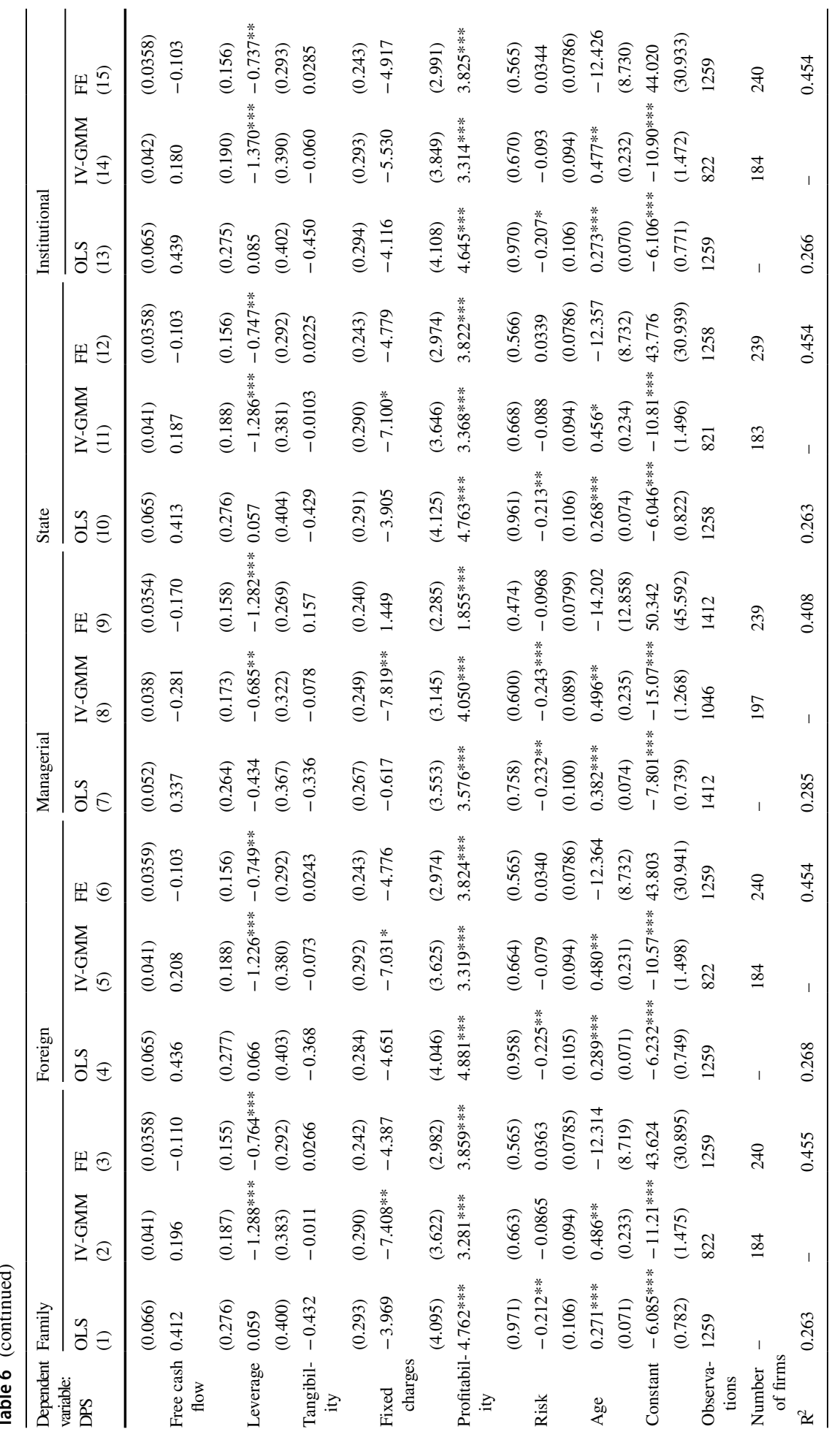




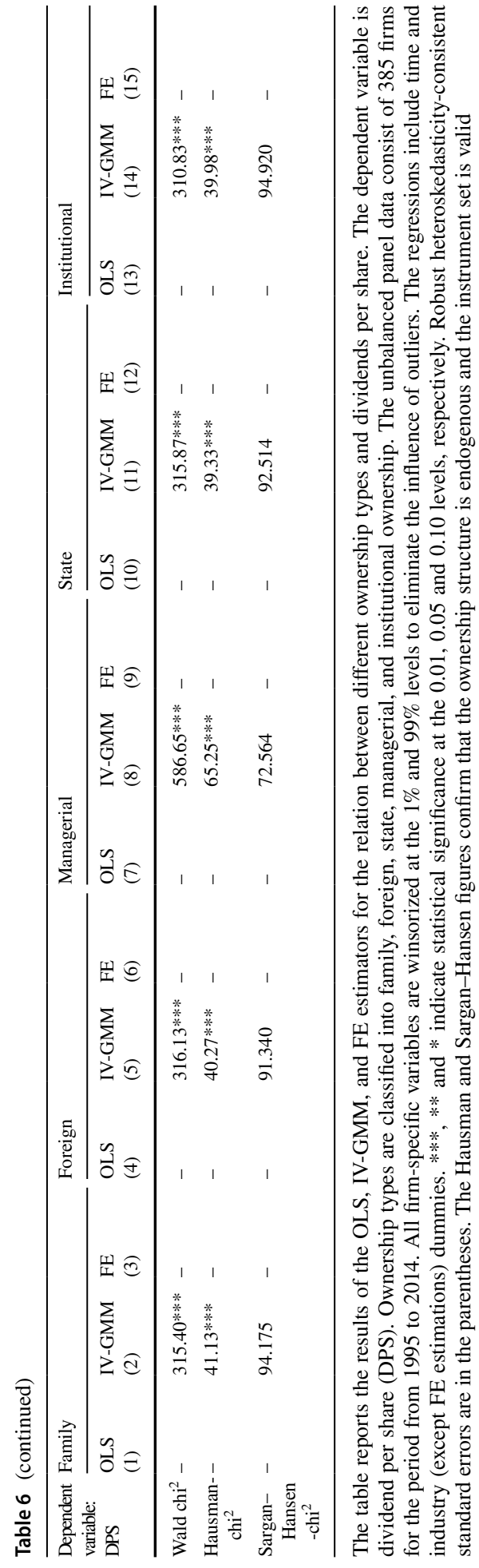


particularly under the OLS setting. However, only managerial ownership yields consistent estimates under both the OLS and IV-GMM methods. The relation between foreign ownership and dividends indicates that firms with higher levels of foreign ownership pay less dividends, which contradicts our hypothesis (H5). This suggests that foreign investors do not consider the asymmetry of information with regards to domestic investors. In other words, they perceive that risk associated with their investment in IDX firms can be effectively anticipated by taking some measures. Therefore, they are willing to receive less dividends. An alternative explanation is that foreign investors perform long run investment in IDX firms, and most of the operating profits are retained as a source of internal fund.

The managerial ownership has a positive and significant relation with dividends, supporting our hypothesis $(H 7)$. As proposed by the agency theory, higher managerial ownership reduces agency cost because it gives better alignment between the interests of the agents and shareholders. Additionally, the negative relation between institutional ownership and dividends implies that such institutions (pension funds, mutual funds, insurance firms, and other financial institutions) do not have any strong influence on a firm's dividend policy. This differs with the typical institutional investors in developed countries whereby they can exert considerable influence upon firms' top management team and force the firm toward value maximization regardless of managers' ownership position (McConnell and Servaes 1990). ${ }^{8}$

\subsection{The level of dividend payments: DIVTA as dependent variable}

Table 7 presents the OLS, IV-GMM, and FE estimation results with DIVTA as the dependent variable. Overcash shows a positive relation with dividends, but their coefficients are statistically weak except for the IV-GMM in model (8). The positive relation supports Hypothesis 1b, suggesting that firms with overcash pay larger dividends. The overinvestment variable has a negative coefficient as predicted, but their relation with dividends is insignificant in most models, except in FE under manageriall. However, by treating manageriall as an endogenous variable, overinvestment coefficients are significant and positive. Moreover, by examining the negative signs, these results are consistent with the prediction of Hypothesis $2 \mathrm{~b}$ explaining that firms with overinvestment pay less dividends.

As for the concentration variable, Table 7 reveals that concentration is a strong determinant of the level of dividend payments. The finding suggests that, in line with Hypothesis 3 b, firms with higher concentration pay larger dividends. This demonstrates that main shareholders can control the managers' decision to disburse the firm's cash as dividends. This also means that by pressuring managers to pay larger dividends, the main shareholders attempt to mitigate the risk of the firm's cash being used by managers.

On the other hand, as predicted in Hypothesis $4 \mathrm{~b}$, the regressions provide some evidence that family ownership has a negative relation with dividends as an indication of the expropriation risk. Foreign investors require larger dividends as shown by the positive and significant coefficient in model (4). As predicted by the asymmetric information hypothesis, foreign investors would like to minimize risk by requesting higher dividend payments to

\footnotetext{
${ }^{8}$ In unreported results, we re-estimate the models in Tables 5 and 6 after controlling for the economic shocks experienced by the Indonesian market (namely the 1997-1998 Southeast Asia economic crisis and the 2007/2008 financial crisis) and macroeconomic changes due to business cycle changes affecting emerging markets (namely GDP, stock market index, and interest rates). Our main results still hold and did not reveal any qualitative difference. These unreported tables are available upon request from the authors.
} 


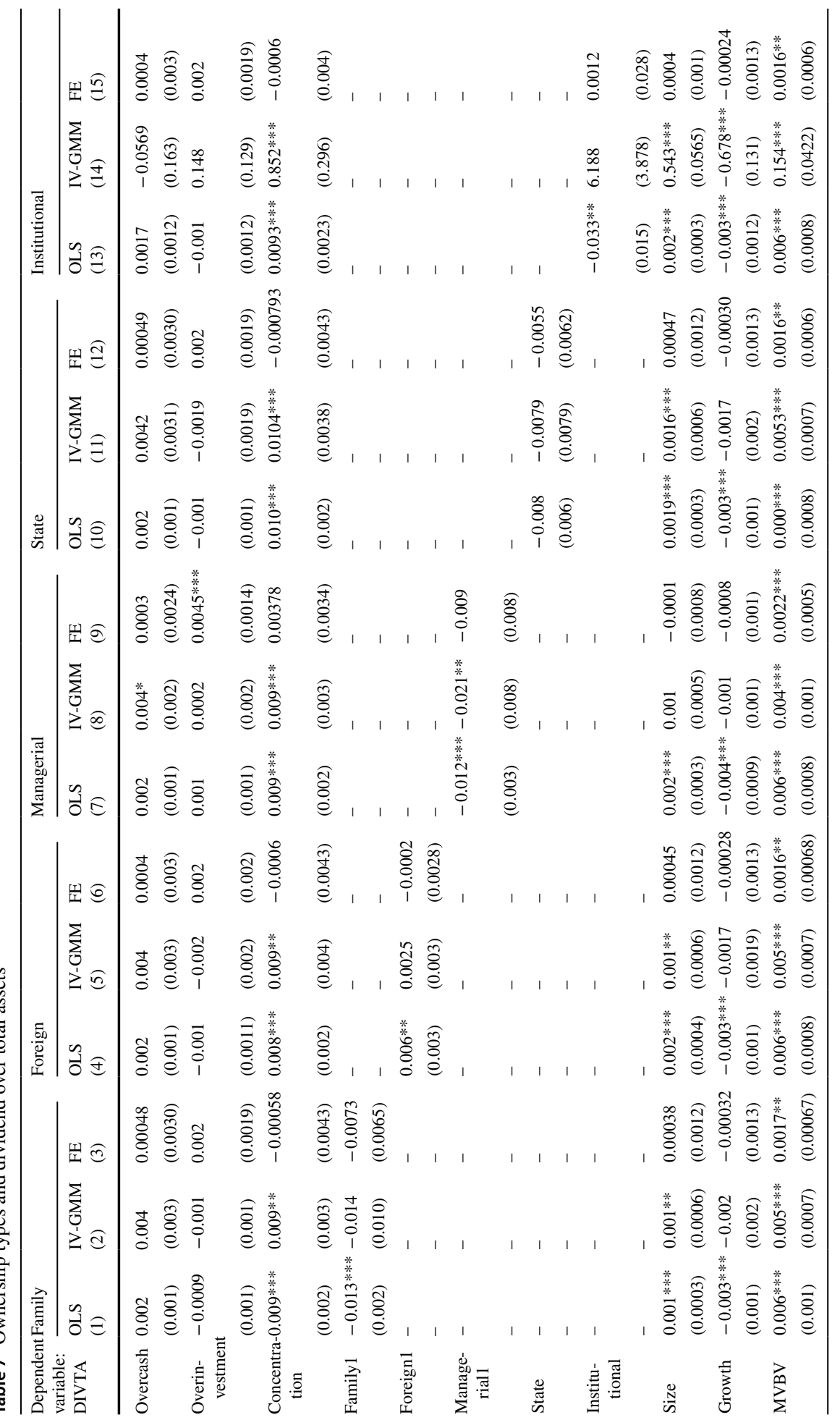




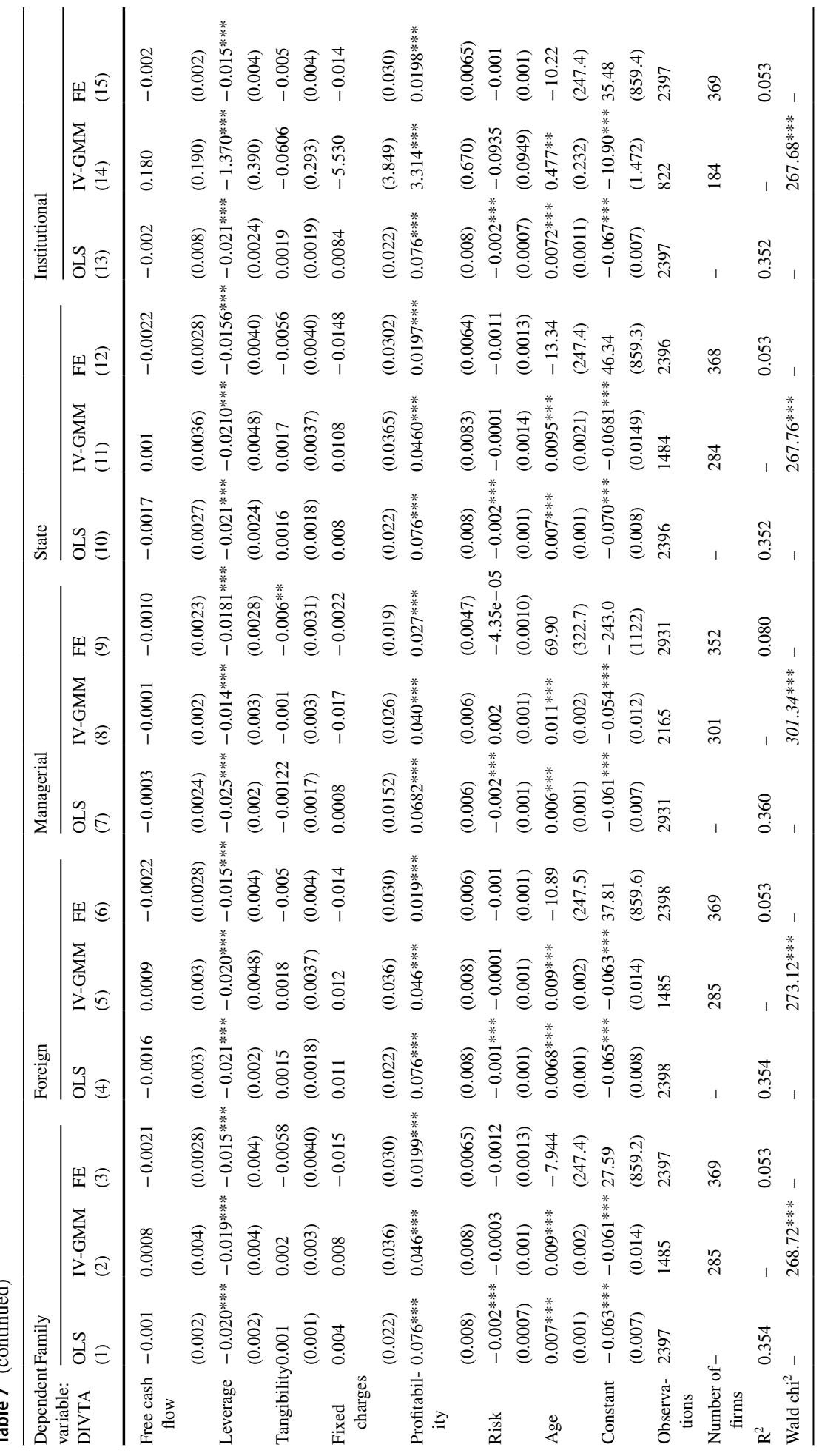




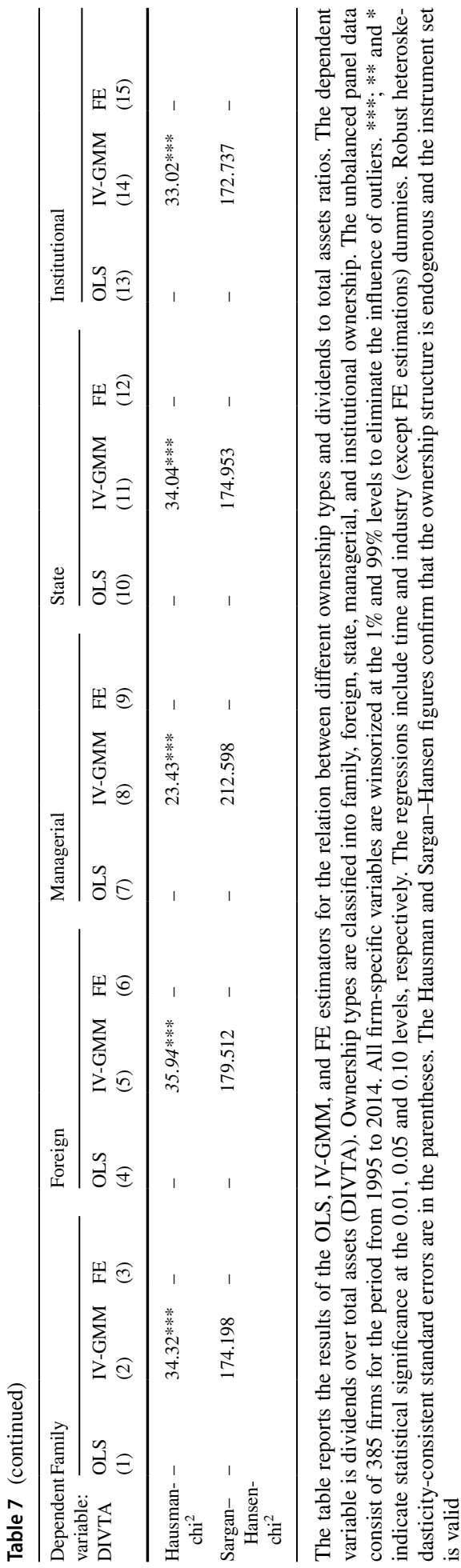


mitigate country risk. Managerial ownership has a negative and significant coefficient with the level of dividends. This result is contrary to Hypothesis $(\mathrm{H} 5 \mathrm{~b})$ stating that their relation should be positive. However, the results in models 7 and 8 show that firms with higher managerial ownership pay lower dividends. A possible explanation for this is that, as echoed by the free cash flow hypothesis, managers require firms to retain free cash flow by minimizing the distribution of dividends as they could use free cash in the pursuit of their own interests.

Table 7 also shows that state ownership (State1) is negatively correlated to dividends but the link is insignificant. In the SOEs, as financially healthy firms, the negative coefficients indicate that the government has retained much of firms' profit by limiting the payment of dividends. There are two explanations regarding this: first, the government would increase their stake by accumulating retained profits to finance firms' growth; second, the government retains the profit to be tunnelled to subsidize other SOEs.

The coefficients of institutional ownership are mixed: OLS yields a negative sign but IV-GMM and FE have positive signs. The relation between institutional ownership and dividend payments under the OLS method is significant and negative, which does not support Hypothesis $8 \mathrm{~b}$ that predicts a positive association. This suggests that institutional investors cannot control dividend decisions due to low equity stakes they are allowed to hold. This maybe because Indonesia's capital market regulations limit the maximum shareholdings held by institutional investors.

\subsection{Heckman two-step procedure}

Table 8 presents the OLS regression, and Table 9 presents the Heckman two-step procedure with DPS (Panel A) and DIVTA (Panel B) as dependent variables. In these regressions, different types of ownership are inputted into the models by combining the variables into one model. In Table 8 Panel A, overcash and concentration are strongly correlated to DPS. These results are consistent with our hypotheses $(H 1 b$ and $H 3 b)$. In contrast, overinvestment has a negative and insignificant link with DPS. All family variables as shown in model 1-3 have negative but insignificant relations with DPS. In addition, the foreign and institutional variables have significantly negative relations with DPS, suggesting that the higher the stock ownership by those types of shareholders, the less dividends are paid by the firms. The negative relation between foreign ownership and dividends contradicts our hypothesis (H5). One explanation for this finding is that foreign owners are more interested in portfolio investment to realize capital gains rather than being strategic investors that expect dividends.

Table 8 also shows that only managerial ownership has a positive relation with DPS, indicating that managers tend to disburse firms' cash, rather than the cash is being retained by the firm. Further, institutional ownership has a negative and significant impact on dividend payments. The result does not support Hypothesis $8 \mathrm{~b}$ predicting that there is a positive association between the institutional ownership and cash dividends.

Table 8 Panel B shows that coefficients of overcash, overinvestment and concentration give similar results to those in Panel A. Family ownership (family1) in Panel B has a negative and significant coefficient, supporting the expropriation hypothesis in the IDX firms. The coefficient of foreign 1 is positive and significant, suggesting that foreign investors require higher dividends to compensate the risks of doing business in Indonesia. Moreover, managerial ownership (managerial1 and managerial3) has a negative effect, indicating that managers could use the firm's cash to maximize their interests by distributing less dividend to other shareholders.

Table 9 exhibits the Heckman regression results. Overcash is strongly correlated with dividends in all models under DPS and DIVTA. This supports our hypothesis $(H 1 b)$ stating that firms with overcash pay larger dividends. Overinvestment has negative and significant 


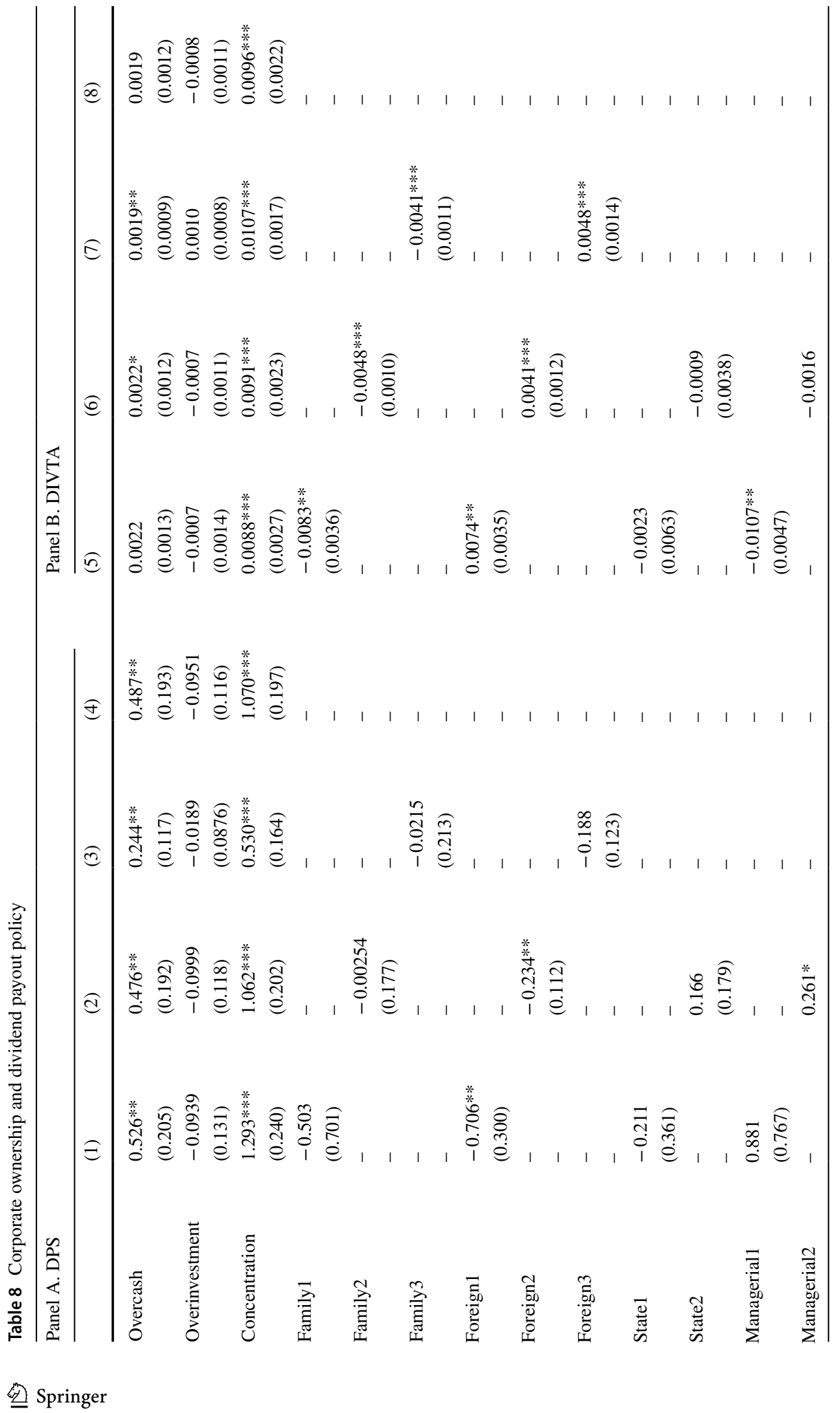




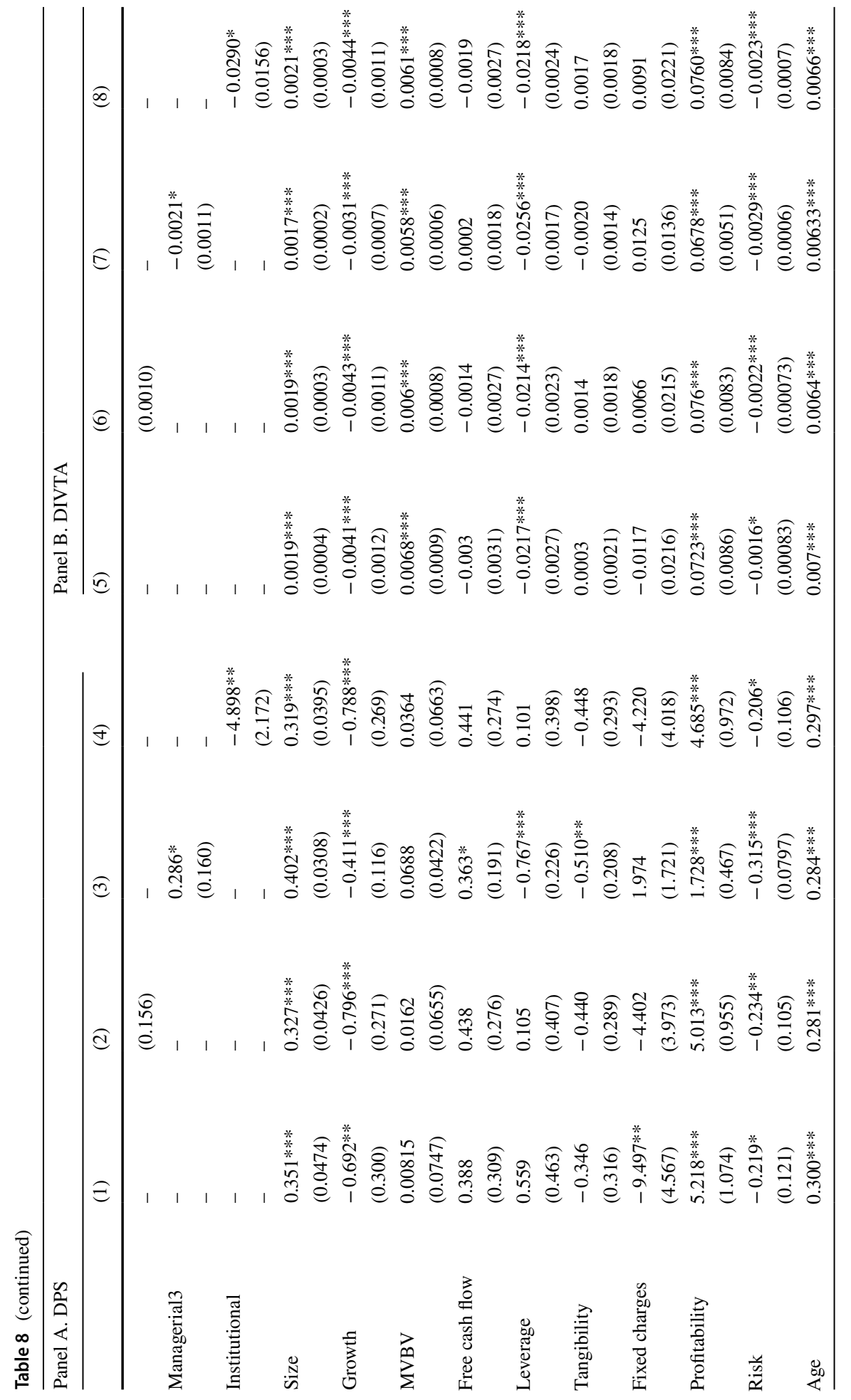




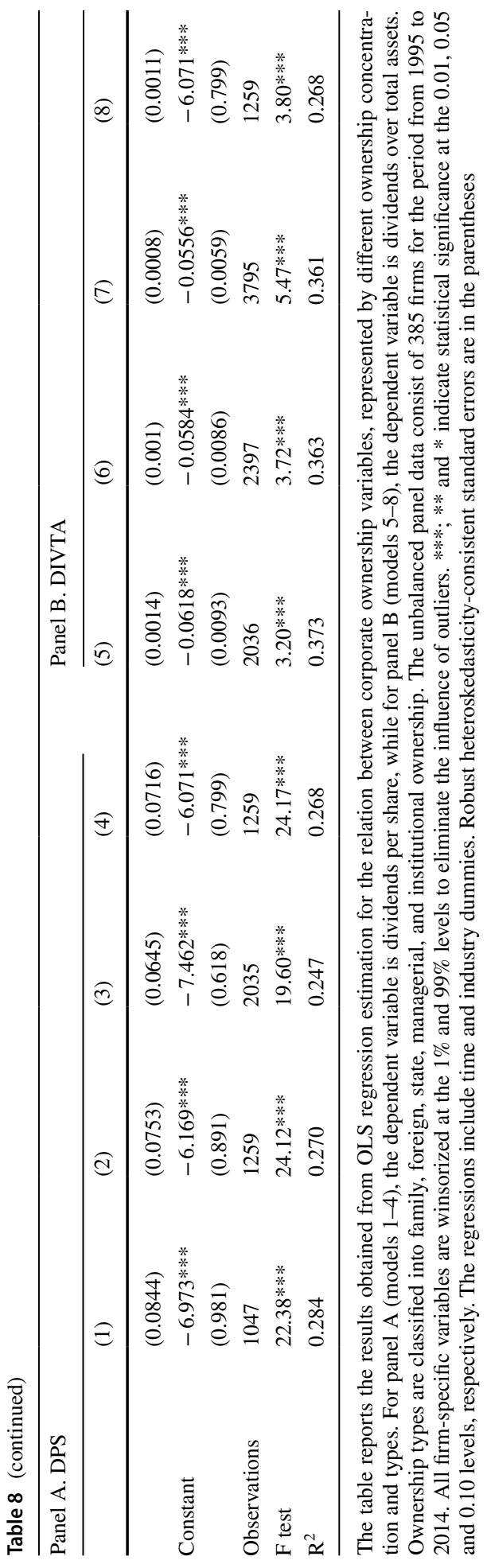




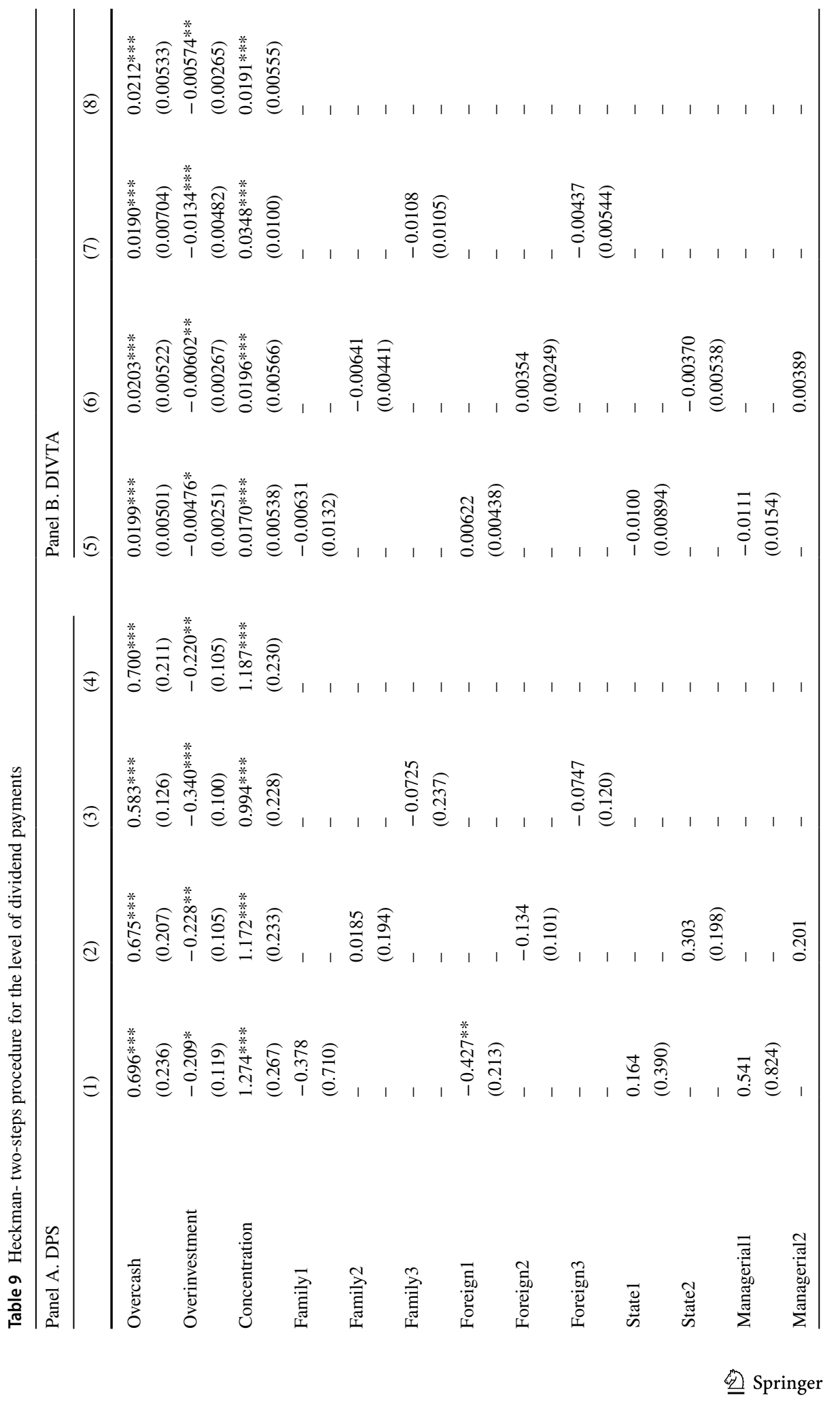




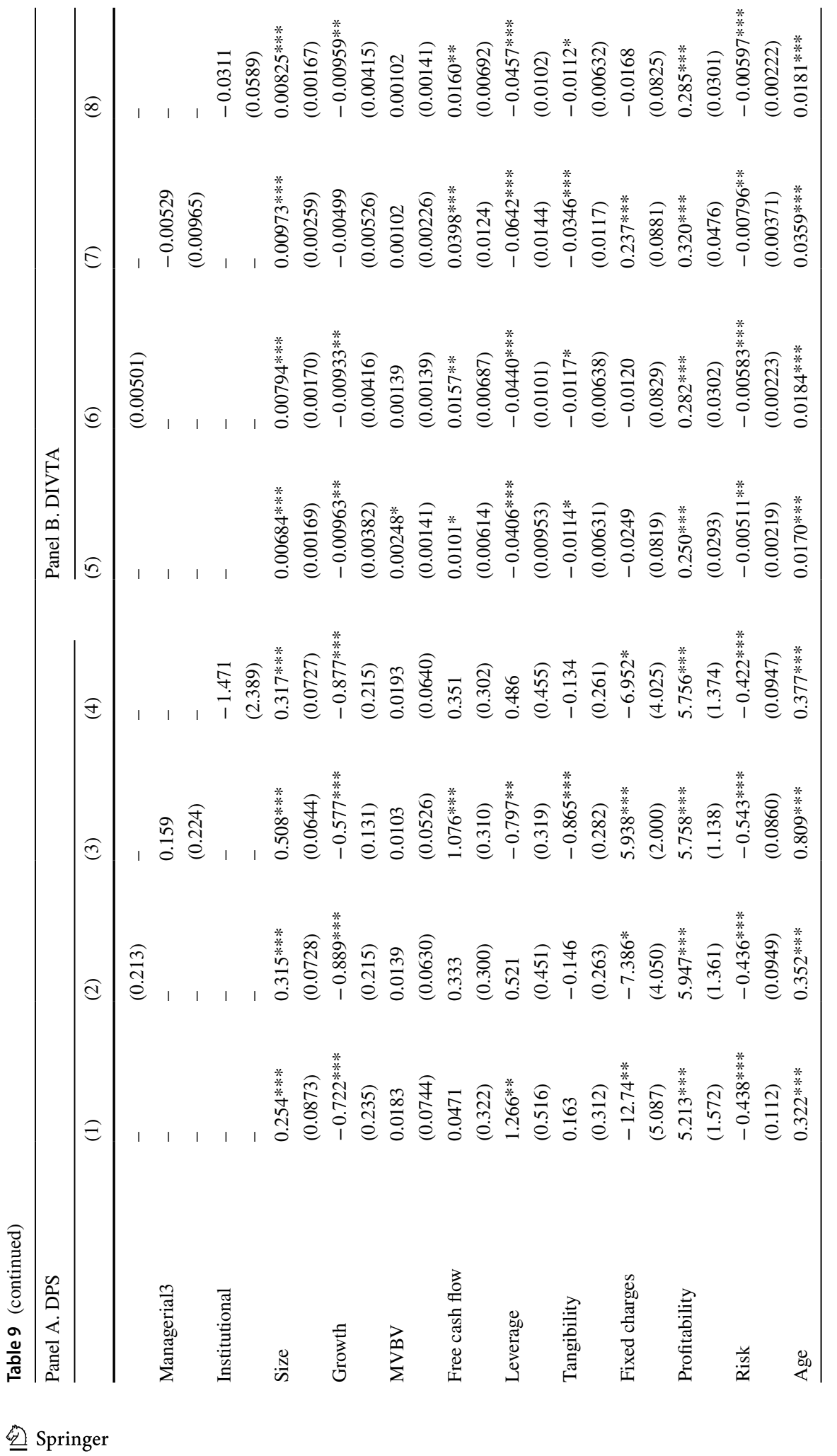




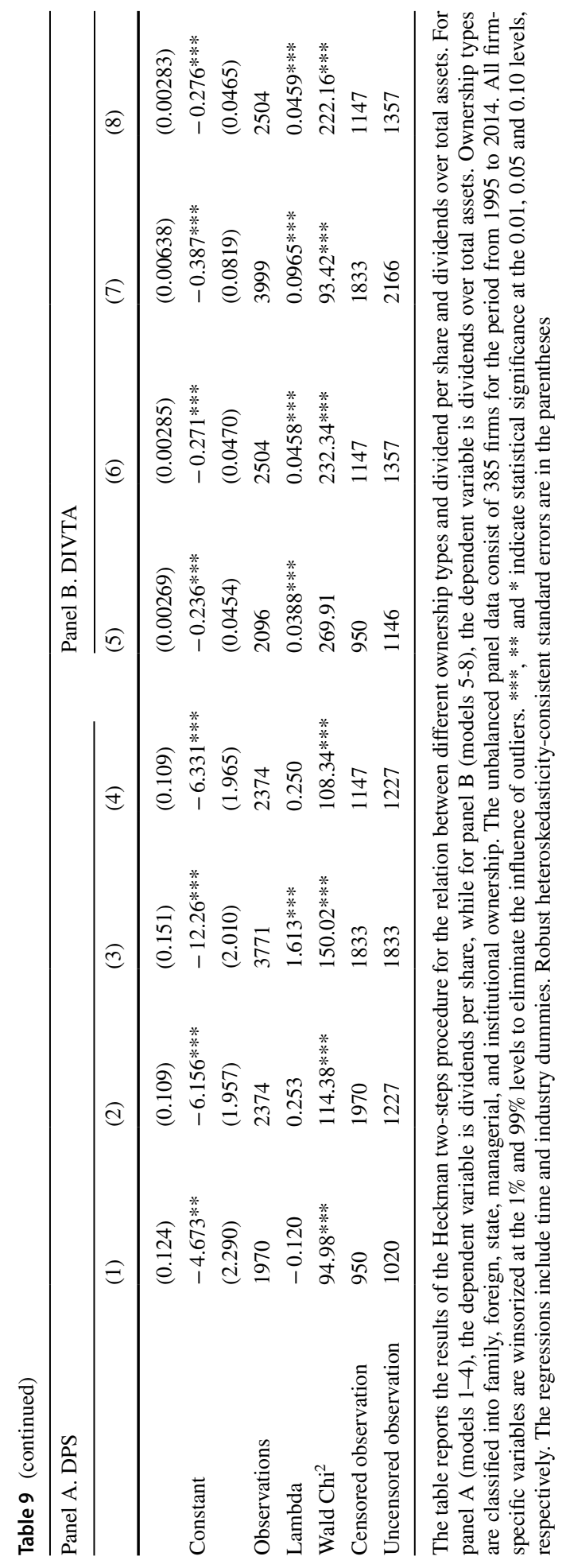


coefficients, which supports our hypothesis $(H 2 b)$ arguing that firms with overinvestment pay lower dividends. On the other hand, ownership concentration is significantly and positively related to dividends. However, this result does not support our hypothesis $(H 3 b)$ stating that firms with higher concentrated ownership tend to accumulate more cash and therefore pay less dividends.

With regards to the types of ownership, Table 8 reports more statistically significant coefficients when compared to Table 9, suggesting that without considering sample selection bias, all types of ownership, except State, have strong relations with dividends. The negative and significant coefficients between those variables and level of dividends imply that firms pay less dividends when these types of ownership increase. On the other hand, when the analysis considers sample selection bias, only foreign ownership has a significant coefficient with negative signs, indicating that the more stocks are held by foreign investors, the less dividends are paid. The use of the Heckman procedure is intended to control firm samples which could be identified as firms having a significant relation for the propensity and the intensity to pay dividends. Furthermore, comparing the OLS with the Heckman two-step procedure is intended to deeply analyze the characteristics of the sample, ensuring the predicted statistical results are more accurate. By examining the lower parts of Table 9 Panel A, the values of Mill's lambda are statistically insignificant except in model 3. In contrast, the Mill's lambda coefficients in Panel B indicate that there is clearly a selection bias in all the models.

Regarding firm-specific variables, the results are generally consistent with those in the previous studies. Size has a positive and strongly significant relation with dividends. Firms with larger assets generally have established managerial and compensation systems, and have effective systems to control managers, which leads to less agency conflicts. Therefore, larger firms pay higher dividends. Current growth, measured by change in sales, has a negative and significant relation with dividends suggesting that firms rely on internal funds by retaining a part of their profits to support their growth rather than by exploiting external financing (Chow et al. 2012). The result supports the hypothesis of dividends as residual, stating that as long as the firms can invest in projects with positive NPV, they would rather use their free cash flows to finance the projects than paying them as dividends to shareholders. Market to book value, as a proxy for future growth, has a positive but insignificant relation with dividends. The positive relation indicates that the higher the future growth prospects, the larger the dividends, suggesting that firms with growth expectations tend to attract prospective and potential investors and retain existing investors by paying larger dividends. Both future and current growth proxies have different signs, indicating that future prospects and historical growth have different effects on the level of dividends.

Leverage has a negative and significant association with dividends. High leverage is a consequence of the availability of funds to pay off the debt and thus affects the magnitude of the level of dividends. The results of the fixed charges variable are consistent with leverage. Firms with high fixed payment charges, i.e., for paying interest and preferred stock dividends, pay less dividends. On the other hand, other results show that leverage has a positive but insignificant relation with dividend as it is combined with the percentage of stock ownership variables (Table 8, model 1). The positive relation indicates that firms could use debt to maintain the level of dividend payment when earnings do not suffice to pay dividends.

Firms gaining higher profitability pay larger dividends as shown by the positive and significant coefficients. In contrast, financial risk, measured by the beta of the firm, has a negative relation with dividends, suggesting that firms with higher risk pay less dividends. This indicates that when firms have high sensitivity and high uncertainty regarding the dynamics of market and industry, they anticipate such conditions by paying dividends and 
retaining more availability of cash in the firm. Finally, age has a strong and positive relation with dividends, indicating that the older the firms, the larger the dividends.

\section{Concluding remarks}

Using a sample of Indonesian listed firms we assess whether a firm's decision to deviate from optimal targets by having overcash holdings and overinvesting affects the dividend payout policy; and evaluate the role of corporate governance represented by different ownership structure and types on the firm's likelihood of altering its dividends payout decisions.

Without controlling for sample selection bias, overcash and concentration significantly and positively affect a firm's intensity to pay dividends. Similar with the propensity for paying dividends, family ownership has a negative association with the intensity of paying dividends, suggesting that firms with higher family ownership pay less dividends. The findings suggest that corporate managers are under strict control by family-related shareholders and they have made dividend decisions to the detriment of minority shareholders. Hence, the findings support the expropriation hypothesis, by which the rights of minority interests are put at risk by family stock owners.

Heckman two-step procedures reveal other important results as sample selection bias is considered. Overcash, overinvestment and level of concentration strongly affect the intensity of dividend payments. In contrast, the ownership variables of ownership, family, foreign, state and institutional have negative and significant associations with dividends. This signals the expropriation of firms' wealth by majority shareholders. These findings strongly support the hypothesis which commonly applies to firms with higher level of concentration or to firms in a weak legal environment. However, foreign ownership negatively affects dividends payout, similar to family ownership, indicating that they require the firm's cash to be reinvested into the firm or, in contrast, use the firm's cash to be shifted to other businesses among their business groups.

The implications of this study encompass three aspects: academic, theoretical, and practical. Academically, this is the first study to examine the association between overcash, overinvestment and dividends policy by focusing on emerging markets, particularly in a country with a high level of ownership concentration, Indonesia. Theoretically, this study contributes to the corporate finance literature in association with agency theory and corporate governance which relates to the disclosure of empirical evidence of expropriation undertaken by controlling shareholders. Practically, the findings of this study can be a reference for the Indonesian Capital Market Supervisory Board to make strategic decisions or regulations regarding the protection of minority shareholders.

Open Access This article is licensed under a Creative Commons Attribution 4.0 International License, which permits use, sharing, adaptation, distribution and reproduction in any medium or format, as long as you give appropriate credit to the original author(s) and the source, provide a link to the Creative Commons licence, and indicate if changes were made. The images or other third party material in this article are included in the article's Creative Commons licence, unless indicated otherwise in a credit line to the material. If material is not included in the article's Creative Commons licence and your intended use is not permitted by statutory regulation or exceeds the permitted use, you will need to obtain permission directly from the copyright holder. To view a copy of this licence, visit http://creativecommons.org/licenses/by/4.0/.

\section{Appendix}

See Table 10. 


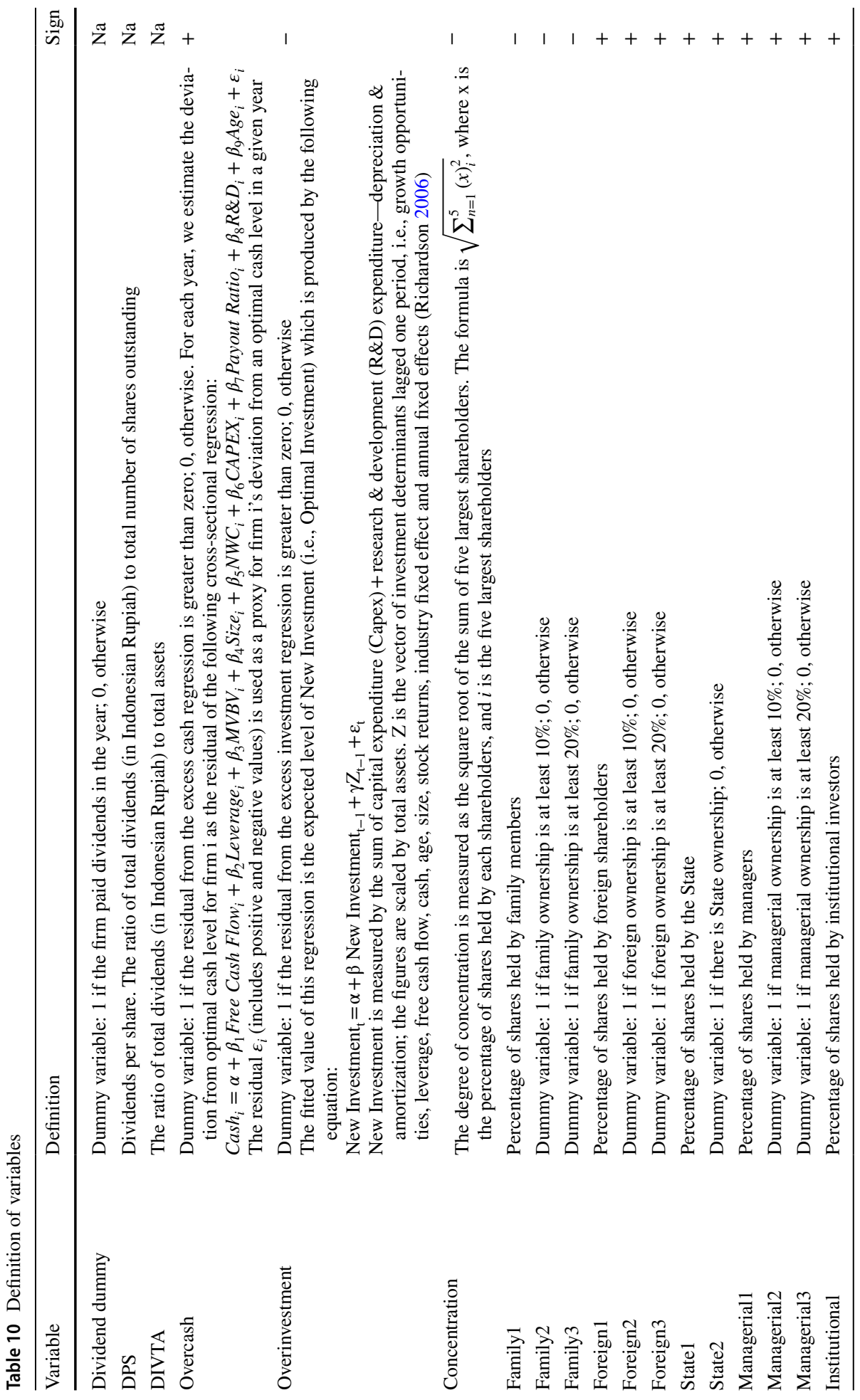




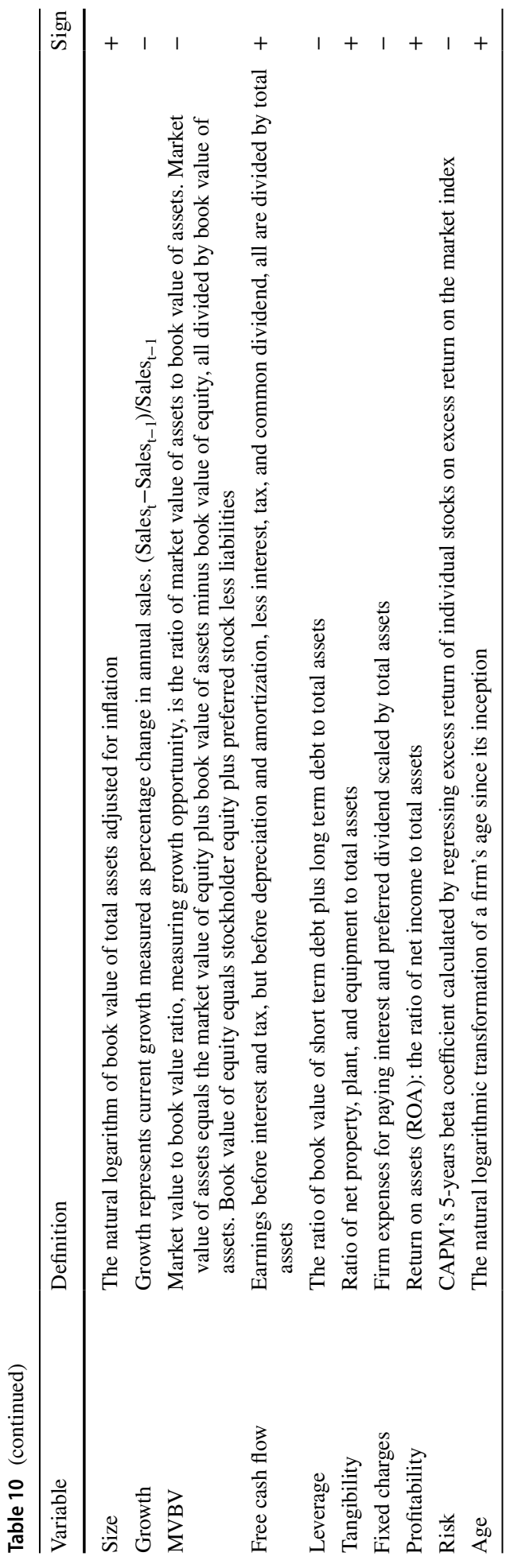




\section{References}

Ahmed AS, Duellman S (2013) Managerial overconfidence and accounting conservatism. J Account Res 51:1-30

Aivazian V, Booth L, Cleary S (2003) Do emerging market firms follow different dividend policies from US firms? J Finan Res 26:371-387

Allen F, Michaely R (2003) Payout policy. Handb Econ Finance 1:337-429

Allen F, Bernardo AE, Welch I (2000) A theory of dividends based on tax clienteles. J Finance 55:2499-2536

Ang JS, Fatemi A, Tourani-Rad A (1997) Capital structure and dividend policies of Indonesian firms. Pac Basin Finance J 5:87-103

Antoniou A, Guney Y, Paudyal K (2008) The determinants of capital structure: capital market-oriented versus bank-oriented institutions. J Financ Quant Anal 43:59-92

Arellano M, Bond S (1991) Some tests of specification for panel data: Monte Carlo evidence and an application to employment equations. Rev Econ Stud 58:277-297

Baker HK, Chang B, Dutta S, Saadi S (2012) Why firms do not pay dividends: the Canadian experience. J Bus Financ Account 39:1330-1356

Bates TW (2005) Asset sales, investment opportunities, and the use of proceeds. J Finance 60:105-135

Ben-Nasr H (2015) Government ownership and dividend policy: evidence from newly privatised firms. J Bus Financ Account 42:665-704

Bertrand M, Mehta P, Mullainathan S (2000) Ferreting out tunneling: an application to Indian business groups. Quart J Econ 117(1):121-148

Blundell R, Bond S (1998) Initial conditions and moment restrictions in dynamic panel data models. J Econom 87:115-143

Borokhovich KA, Brunarski KR, Harman Y, Kehr JB (2005) Dividends, corporate monitors and agency costs. Financ Rev 40:37-65

Che X, Liebenberg AP, Liebenberg IA, Morris BC (2018) The effect of growth opportunities on the market reaction to dividend cuts: evidence from the 2008 financial crisis. Rev Quant Finance Account 51:1-17

Chen X, Sun Y, Xu X (2016) Free cash flow, over-investment and corporate governance in China. Pac Basin Finance J 37:81-103

Chow CKW, Fung MKY, Lam KC, Sami H (2012) Investment opportunity set, political connection and business policies of private enterprises in China. Rev Quant Finance Account 38:367-389

Claessens S, Djankov S, Fan JP, Lang LH (2002) Disentangling the incentive and entrenchment effects of large shareholdings. J Finance 57:2741-2771

Denis DJ, Osobov I (2008) Why do firms pay dividends? International evidence on the determinants of dividend policy. J Financ Econ 89:62-82

Ding S, Knight J, Zhang X (2016) Does China overinvest? Evidence from a panel of Chinese firms. Eur J Finance 25:489-507

Dittmar A, Mahrt-Smith J (2007) Corporate governance and the value of cash holdings. J Financ Econ 83:599-634

Duygun M, Guney Y, Moin A (2018) Dividend policy of Indonesian listed firms: the role of families and the state. Econ Model 75:336-354

Easterbrook FH (1984) Two agency-cost explanations of dividends. Am Econ Rev 74:650-659

Eisdorfer A, Giaccotto C, White R (2015) Do corporate managers skimp on shareholders' dividends to protect their own retirement funds? J Corp Finance 30:257-277

El Kalak I, Tosun OK (2019) Female directors, CEO overconfidence and excess cash. Unpublished working paper, SSRN. http://dx.doi.org/10.2139/ssrn.3366827

Faccio M, Lang LH, Young L (2001) Dividends and expropriation. Am Econ Rev 91:54-78

Fairchild R (2010) Dividend policy, signalling and free cash flow: an integrated approach. Manag Finance 36:394-413

Fama EF, French KR (2001) Disappearing dividends: changing firm characteristics or lower propensity to pay? J Financ Econ 60:3-43

Fu F (2010) Overinvestment and the operating performance of SEO firms. Financ Manag 39:249-272

Fuller K, Blau BM (2010) Signaling, free cash flow and "nonmonotonic" dividends. Financ Rev 45:21-56

Guariglia A, Yang J (2016) A balancing act: managing financial constraints and agency costs to minimize investment inefficiency in the Chinese market. J Corp Finance 36:111-130

Gugler K (2003) Corporate governance, dividend payout policy, and the interrelation between dividends, R\&D, and capital investment. J Bank Finance 27:1297-1321

Gul FA, Kealey BT (1999) Chaebol, investment opportunity set and corporate debt and dividend policies of Korean companies. Rev Quant Finance Account 13:401-416 
Guo J (2016) Ultimate controlling shareholders and dividend payout policy in Chinese stock market. Rev Pac Basin Financ Mark Policies 19:1650008

Harford J (1999) Corporate cash reserves and acquisitions. J Finance 54:1969-1997

Harford J, Mansi SA, Maxwell WF (2008) Corporate governance and firm cash holdings in the US. J Financ Econ 87:535-555

Holder ME, Langrehr FW, Hexter JL (1998) Dividend policy determinants: an investigation of the influences of stakeholder theory. Financ Manag 27:73-82

$\mathrm{Hu}$ A, Kumar P (2004) Managerial entrenchment and payout policy. J Financ Quant Anal 39:759-790

Jacob M, Michaely R (2017) Taxation and dividend policy: the muting effect of agency issues and shareholder conflicts. Rev Financ Stud 30:3176-3222

Jain P, Chu QC (2014) Dividend clienteles: a global investigation. Rev Quant Finance Account 42:509-534

Jensen MC (1986) Agency cost of free cash flow, corporate finance, and takeovers. Am Econ Rev 76:323-329

Jensen MC, Meckling WH (1976) Theory of the firm: managerial behavior, agency costs and ownership structure. J Financ Econ 3:305-360

Jensen MC, Meckling WH (1979) Theory of the firm: managerial behavior, agency costs, and ownership structure. Springer, Berlin

Jeon JQ, Lee C, Moffett CM (2011) Effects of foreign ownership on payout policy: evidence from the Korean market. J Financ Mark 14:344-375

Jiang Z, Lie E (2016) Cash holding adjustments and managerial entrenchment. J Corp Finance 36:190-205

Jiang F, Ma Y, Shi B (2017) Stock liquidity and dividend payouts. J Corp Finance 42:295-314

Kim B, Jung K, Kim IJ (2005) Internal funds allocation and the ownership structure: evidence from Korean business groups. Rev Quant Finance Account 25:33-53

Kim HJ, Jo H, Yoon SS (2013) Controlling shareholders' opportunistic use of share repurchases. Rev Quant Finance Account 41:203-224

Kuo N-T (2013) Dividend tax signaling and the pricing of future earnings: a case of taxable stock dividends. Rev Quant Finance Account 40:539-570

La Porta R, Lakonishok J, Shleifer A, Vishny R (1997) Good news for value stocks: further evidence on market efficiency. J Finance 52:859-874

La Porta R, Lopez-de-Silanes F, Shleifer A, Vishny R (2000a) Investor protection and corporate governance. J Financ Econ 58:3-27

La Porta R, Lopez-de-Silanes F, Shleifer A, Vishny RW (2000b) Agency problems and dividend policies around the world. J Finance 55:1-33

Lang L, Poulsen A, Stulz R (1995) Asset sales, firm performance, and the agency costs of managerial discretion. J Financ Econ 37:3-37

Leary MT, Michaely R (2011) Determinants of dividend smoothing: empirical evidence. Rev Financ Stud 24:3197-3249

Leuz C, Oberholzer-Gee F (2006) Political relationships, global financing, and corporate transparency: evidence from Indonesia. J Financ Econ 81:411-439

Leuz C, Wysocki PD (2016) The economics of disclosure and financial reporting regulation: evidence and suggestions for future research. J Account Res 54:525-622

Lin H-C, Chiu S-C (2017) Tradeoff on corporate cash holdings: a theoretical and empirical analysis. Rev Quant Finance Account 49:727-763

McConnell JJ, Servaes H (1990) Additional evidence on equity ownership and corporate value. J Financ Econ 27:595-612

Mikkelson WH, Partch MM (2003) Do persistent large cash reserves hinder performance? J Financ Quant Anal 38:275-294

Miller MH, Modigliani F (1961) Dividend policy, growth, and the valuation of shares. J Bus 34:411-433

Mishra CS, Narender V (1996) Dividend policy of SOEs in India-an analysis. Finance India 10:633-645

Myers SC, Majluf NS (1984) Corporate financing and investment decisions when firms have information that investors do not have. J Financ Econ 13:187-221

Officer MS (2011) Overinvestment, corporate governance, and dividend initiations. J Corp Finance 17:710-724

Opler T, Pinkowitz L, Stulz R, Williamson R (1999) The determinants and implications of corporate cash holdings. J Financ Econ 52:3-46

Pinkowitz L, Stulz R, Williamson R (2006) Does the contribution of corporate cash holdings and dividends to firm value depend on governance? A cross-country analysis. J Finance 61:2725-2751 
Richardson S (2006) Over-investment of free cash flow. Rev Account Stud 11:159-189

Rozeff MS (1984) Dividend yields are equity risk premiums. J Portf Manag 11:68-75

Schooley DK, Barney LD (1994) Using dividend policy and managerial ownership to reduce agency costs. J Financ Res 17:363-373

Shleifer A, Vishny RW (1997) A survey of corporate governance. J Finance 52:737-783

Tee CM, Yee ASV, Chong AL (2018) Institutional investors' monitoring and stock price crash risk: evidence from politically connected firms. Rev Pac Basin Financ Mark Policies 21:1850028

Twu M (2012) Stock market development and the decline of the portion of dividend payers throughout the world. Financ Rev 47:401-421

Wei Z, Varela O (2003) State equity ownership and firm market performance: evidence from China's newly privatized firms. Glob Finance J 14:65-82

Yu H-C, Sopranzetti BJ, Lee C-F (2015) The impact of banking relationships, managerial incentives, and board monitoring on corporate cash holdings: an emerging market perspective. Rev Quant Finance Account 44:353-378

Publisher's Note Springer Nature remains neutral with regard to jurisdictional claims in published maps and institutional affiliations. 